\title{
Morphological and molecular systematic review of Marphysa Quatrefages, 1865 (Annelida: Eunicidae) species from South Africa
}

\author{
Jyothi Kara ${ }^{\text {Equal first author, } 1,2}$, Isabel C. Molina-Acevedo ${ }^{\text {Corresp., Equal first author, } 3,4 \text {, Joana Zanol }}{ }^{5}$, Carol Simon ${ }^{1}$, Izwandy Idris \\ ${ }^{1}$ Department of Botany and Zoology, Stellenbosch University, Private Bag X1, Matieland, Stellenbosch, South Africa \\ 2 Research and Exhibitions Department, Iziko Museums of South Africa, Cape Town, 8000, South Africa \\ 3 South China Sea Repository and Reference Centre, Institute of Oceanography and Environment, Universiti Malaysia Terengganu, Kuala Nerus, \\ Terengganu, Malaysia \\ 4 Estructura y Función del Bentos, Depto. de Sistemática y Ecología Acuática., El Colegio de la Frontera Sur, Chetumal, Quintana Roo, México \\ 5 Departamento de Invertebrados, Museu Nacional, Universidade Federal do Rio de Janeiro, Quinta da Boa Vista, São Cristovão, Brazil \\ Corresponding Author: Isabel C. Molina-Acevedo \\ Email address: imolina@ecosur.edu.mx
}

A vast polychaete fauna is hidden behind complexes of cryptic and pseudo-cryptic species, which has greatly hindered our understanding of species diversity in several regions worldwide. Among the eunicids, Marphysa sanguinea (Montagu, 1813) is a typical example, recorded in three oceans and with various species considered its junior synonyms. In South Africa, specimens previously misidentified as $M$. sanguinea are now known as M. elityeni Lewis \& Karageorgopoulos, 2008. Of the six Marphysa Quatrefages, 1865 species recorded from the same region, three have their distributions restricted to South Africa while the others are considered to have worldwide distributions. Here, we evaluated the taxonomic status of the indigenous $M$. elityeni and investigated the presence of the widespread species M. macintoshi Crossland, 1903 and Marphysa depressa (Schmarda, 1861) in South Africa using morphological and molecular data. Our results reveal that Marphysa elityeni is a junior synonym of $M$. haemasoma, a species previously described from South Africa which is herein reinstated as a valid species. Both Marphysa macintoshi and M. depressa are not present in South Africa and their status as being distributed worldwide deserves further investigation. Marphysa durbanensis Day, 1934 and the new species described here, M. sherlockae n. sp., had been, respectively, misidentified as $M$. macintoshi and M. depressa. Thus, the number of Marphysa species with distributions restricted to South Africa increased from three to five. This study reiterates the importance of implementing an integrated taxonomic framework to unravel local biodiversity. 
1 Morphological and molecular systematic review of 2 Marphysa Quatrefages, 1865 (Annelida: Eunicidae) 3 species from South Africa.

4

5

6

7

8

9

10

11

12

13

14

15

16

17

18

19

20

21

22

23

24

25

26

27

28

29

30

31

32

33

34

35

36

37

38

39

40

41

42

43

44

45

Jyothi Kara equal first author1,2, Isabel C. Molina-Acevedo equal first author 3,4, Joana Zanol ${ }^{5}$, Carol A.

Simon ${ }^{1}$, Izwandy Idris ${ }^{3}$

${ }^{1}$ Department of Botany and Zoology, Stellenbosch University, Private Bag X1, Matieland, Stellenbosch, 7602, South Africa.

${ }^{2}$ Research and Exhibitions Department, Iziko Museums of South Africa, Cape Town, 8000, South Africa.

${ }^{3}$ South China Sea Repository and Reference Centre, Institute of Oceanography and Environment, Universiti Malaysia Terengganu, 21030 Kuala Nerus, Terengganu, Malaysia

${ }^{4}$ Estructura y Función del Bentos, Depto. Sistemática y Ecología Acuática, El Colegio de la Frontera Sur, Chetumal, Quintana Roo, México.

${ }^{5}$ Departamento de Invertebrados, Museu Nacional, Universidade Federal do Rio de Janeiro, Quinta da Boa Vista, São Cristovão, RJ, 20940-040 Brazil.

Corresponding Author:

Isabel C. Molina-Acevedo 3,4

South China Sea Repository and Reference Centre, Institute of Oceanography and Environment, Universiti Malaysia Terengganu, 21030 Kuala Nerus, Terengganu, Malaysia.

Email address: isacrismoliace@gmail.com, imolina@ecosur.edu.mx, isabel.molina@umt.edu.my

\section{Abstract}

A vast polychaete fauna is hidden behind complexes of cryptic and pseudo-cryptic species, which has greatly hindered our understanding of species diversity in several regions worldwide. Among the eunicids, Marphysa sanguinea (Montagu, 1813) is a typical example, recorded in three oceans and with various species considered its junior synonyms. In South Africa, specimens previously misidentified as M. sanguinea are now known as M. elityeni Lewis \& Karageorgopoulos, 2008. Of the six Marphysa Quatrefages, 1865 species recorded from the same region, three have their distributions restricted to South Africa while the others are considered to have worldwide distributions. Here, we evaluated the taxonomic status of the indigenous M. elityeni and investigated the presence of the widespread species M. macintoshi Crossland, 1903 and Marphysa depressa (Schmarda, 1861) in South Africa using morphological and molecular data. Our results reveal that Marphysa elityeni is a junior synonym of M. haemasoma, a species previously described from South Africa which is herein reinstated as a valid species. Both Marphysa macintoshi and M. depressa are not present in South Africa and their status as being distributed worldwide deserves further investigation. Marphysa durbanensis Day, 1934 and the new species described here, M. sherlockae n. sp., had been, respectively, misidentified as M. macintoshi and 
49

50

51

52

53

54

55

56

57

58

59

60

61

62

63

64

65

66

67

68

69

70

71

72

73

74

75

76

77

78

79

80

81

82

83

84

85

86

87

88

89

90

91

M. depressa. Thus, the number of Marphysa species with distributions restricted to South Africa increased from three to five. This study reiterates the importance of implementing an integrated taxonomic framework to unravel local biodiversity.

Keywords: COI sequences, distribution, morphology, new species, diversity.

\section{Introduction}

Studies implementing molecular and morphological tools in an integrated framework have found that a large portion of polychaete diversity has been hidden among complexes of cryptic and pseudo-cryptic species (Knowlton 1993; Nygren 2014; Hutchings \& Kupriyanova 2018). Thus, unravelling these species complexes can uncover patterns of distribution, regional biodiversity, and areas of endemism of previously overlooked polychaete species, which could have management and conservation implications (Bickford et al. 2007; Nygren 2014).

Species belonging to Marphysa Quatrefages, 1865 (Quatrefages 1865a,b), which serve as important bait species around the world (Izuka 1912; Lewis \& Karageorgopoulos 2008; Idris et al 2014; Liu et al. 2017; Lavesque et al. 2017; Watson et al. 2017; Cole et al. 2018; Martin et al., 2020), are ideal candidates to investigate the incidence of complexes of pseudo-cryptic species. These complexes are frequently a consequence of very brief original species descriptions, as is Marphysa sanguinea (Montagu, 1813), type species of the genus (Hutchings \& Karageorgopoulos, 2003). As a result of the brief species description, several morphologically similar species from far-flung places globally were considered junior synonyms of M. sanguinea (Hutchings \& Karageorgopoulos 2003; Molina-Acevedo \& Carrera-Parra 2015). As a consequence, its already broad distribution range was expanded, and it was reported to occur in Spain (Parapar et al. 1993), South Africa (Day 1967), Australia (Day 1967), Mexican Caribbean (Salazar-Vallejo \& CarreraParra 1998) and Japan (Miura 1986) among others.

However, the detailed redescription of $M$. sanguinea and designation of the neotype (Hutchings \& Karageorgopoulos 2003) resulted in the reinstatement of at least three junior synonyms as valid species, including M. acicularum Webster, 1884, M. nobilis Treadwell, 1917, and M. viridis Treadwell, 1917 (e.g., Molina-Acevedo \& Carrera-Parra 2015; Molina-Acevedo \& Idris, 2020). Furthermore, several new species with restricted distributions were described (e.g., Hutchings \& Karageorgopoulos 2003; Glasby \& Hutchings 2010; Zanol et al. 2016; Zanol et al. 2017; Liu et al. 2017; Martin et al. 2020), some of which had been erroneously identified as $M$. sanguinea (e.g., Hutchings \& Karageorgopoulos 2003; Lewis \& Karageorgopoulos 2008; Lavesque et al. 2017; Wang et al. 2018). Detailed observations of specimens demonstrated the variability in diagnostic characters, like branchial distribution, parapodia shape, types of pectinate chaetae, coloration and shape of subacicular hooks, for Marphysa species that had previously been overlooked. The above-mentioned characters may apply to other species such as M. teretiuscula (Schmarda, 1861) and M. macintoshi Crossland, 1903, which also have suspiciously wide distribution ranges (Treadwell 1906, Read \& Fauchald 2018).

Six valid species belonging to Marphysa are currently recognized as present in South Africa. Three have type localities in South Africa; Marphysa capensis (Schmarda, 1861), Marphysa posteriobranchia Day, 196, and Marphysa elityeni Lewis \& Karageorgopoulos, 2008 (Day, 1967; Lewis \& Karageorgopoulos 2008). The latter is commonly known as the "wonder worm" by local fishermen, and is part of the global M. sanguinea species complex (Day 1967;

Peer] reviewing PDF | (2020:05:48929:2:0:NEW 7 Sep 2020) 
92 Lewis \& Karageorgopoulos 2008; Simon et al. 2019). The remaining three Marphysa species 93 recorded for the region, namely M. corallina (Kinberg, 1865), M. depressa (Schmarda, 1861), and 94 M. macintoshi Crossland, 1903 have type localities outside of South Africa and wide distributions 95 (Day 1967). Marphysa depressa has a type locality in Auckland, New Zealand (Schmarda 1861), 96 and has since been recorded in Hong Kong (Wang et al. 2018) and South African estuaries from 97 Saldanha Bay to Durban Bay (Day 1953, 1967). Marphysa macintoshi was described from 98 Zanzibar (Crossland 1903) and has since been recorded from several localities including Australia, 99 South Africa, Caribbean Sea, Mozambique, Red Sea, Trinidad and Tobago and China (Read \& 100 Fauchald 2018). In South Africa, this species is supposedly present from Cape St. Francis to

101

102

103

104

105

106

107

108

109

110

111

112

113

114

115

116

117

118

119

120

121

122

123

124

125

126

127

128

129

130

131

132

133

134

135

136

137 Durban Bay (Day, 1967). Interestingly, M. durbanensis Day, 1934 described from KwaZulu-Natal in South Africa, is considered a junior synonym of M. macintoshi (Day, 1967). Similarly, M. haemasoma Quatrefages, 1866 was described from Table Bay in South Africa and is currently considered a junior synonym of $M$. sanguinea. Thus, both species probably represent valid indigenous species that were incorrectly synonymized.

In this study, we investigated whether M. depressa and M. macintoshi occur in South Africa and examined the taxonomic validity of M. haemasoma. These were achieved by conducting thorough taxonomic revisions and where possible, molecular comparisons. We also provide redescriptions of M. haemasoma, M. durbanensis, and a description of M. sherlockae n. sp., a species new to science from South Africa.

\section{Material and Methods}

\section{Examined material}

Fresh Marphysa depressa-like specimens were collected from rock crevices in the fringing intertidal zones from Strand $(-34.116108,18.821698)(n=4)($ Fig. 1). Fresh specimens of $M$. elityeni were collected from the fringing intertidal zone at low tide from burrows in gravely-sand type sediment under boulders in Kommetjie $(\mathrm{n}=5)(-34.159709$, 18.327851) (Fig. 1). Full collection data for both species can be found in the respective species accounts in the results section. Live specimens were brought back to the laboratory where they were anesthetized with $7 \% \mathrm{MgCl}_{2}$ in distilled water, and photographed. Whole specimens from Strand were fixed in $96 \%$ ethanol. Posterior ends of the Kommetjie specimens were fixed in $96 \%$ ethanol, while the anterior ends were fixed in a $4 \%$ seawater-formalin solution. The collection of live material was approved by The Department of Agriculture, Forestry and Fisheries in South Africa under the permit number RES2019/49.Type and non-type material of $M$. depressa, M. macintoshi, M. durbanensis, $M$. haemasoma and M. elityeni deposited at the Natural History Museum (BMNH), Museum National d'Histoire Naturelle, Paris (MNHN) and the Natural History Museum, Vienna, Austria (NHM) and the Iziko South African Museum (SAM) were examined.

\section{Morphological examination}

Species descriptions were produced based on the type material, but a variation section with all specimens reviewed was also included.

The general structures such as the prostomium, peristomium, anterior region of the body, maxillary apparatus, branchiae, parapodia, chaetae, and pygidium were included in the descriptions. A dorsal incision was made in the specimen to extract and describe the maxillary

PeerJ reviewing PDF | (2020:05:48929:2:0:NEW 7 Sep 2020) 
138

139

140

141

142

143

144

145

146

147

148

149

150

151

152

153

154

155

156

157

158

159

160

161

162

163

164

165

166

167

168

169

170

171

172

173

174

175

176

177

178

179

180

181

182

183

apparatus, after which it was returned to its original position. The maxillary formula (MF) and measurements were taken according to Molina-Acevedo \& Carrera-Parra (2015, 2017). Six parapodia (three from the anterior region, two from the median, and one from the posterior region) were dissected to describe the morphology of the cirri and lobes, and simple and compound chaetae.

The chaetigers where branchiae and subacicular hooks start were indicated depending on the side where they began ('L' for Left, 'R' for Right) with the chaetiger number. In the region with the maximum number of branchial filaments, the long filaments are $\geq 4$ times as long as dorsal cirri, whereas the short filaments are $<4$ times as long as dorsal cirri. The terminology used for the descriptions of the pectinate chaetae is according to the classification proposed by MolinaAcevedo \& Carrera-Parra $(2015,2017)$ and Zanol et al. (2016). Herein, thin and thick refers to the thickness of the pectinate shaft; wide and narrow refers to the width of the pectinate blade; and anodont and isodont refer to the relative length of external teeth in relation to each other and internal teeth, e.g., thin, wide isodont with long and slender teeth.

The length through chaetiger 10 (L10) and the width of chaetiger 10 excluding parapodia (W10) were measured in the specimens as standard measures when the specimens were collected incomplete. Likewise, the total length (TL) and variations of the total number of chaetigers (TChae) were recorded. All descriptions were illustrated with a series of photos taken with Canon EOS T6i. These were then stacked using Helicon Focus ${ }^{\circledR} 6$ (Method A) software to improve the depth of field, and the final editing was performed in Adobe Photoshop ${ }^{\circledR} 2020$.

To understand patterns of intraspecific variation, linear regression analyses were conducted to evaluate the possible relationships between size (length of specimens using L10 measurement) and morphological features such as the chaetigers where branchiae or the subacicular hooks begin, the number of branchial filaments. The degree of predictability of variation in morphological features following size variation is given by $\mathrm{R}^{2}$ (e.g., $\mathrm{R}^{2}=0.63, \mathrm{p}=0.05, \mathrm{n}=34$ ).

The electronic version of this article in Portable Document Format (PDF) will represent a published work according to the International Commission on Zoological Nomenclature (ICZN), and hence the new names contained in the electronic version are effectively published under that Code from the electronic edition alone. This published work and the nomenclatural acts it contains have been egistered in ZooBank, the online registration system for the ICZN. The ZooBank LSIDs (Life Science Identifiers) can be resolved and the associated information viewed through any standard web browser by appending the LSID to the prefix http://zoobank.org/. The LSID for this publication is: urn:1sid:zoobank.org:pub:C4C08B70-EC42-4AE1-9F9A-FDC717142D35 The online version of this work is archived and available from the following digital repositories: PeerJ, PubMed Central and CLOCKSS.

\section{Molecular methods}

\section{DNA extraction, amplification and sequencing}

DNA was extracted from tissue samples using the ZR Genomic DNA Tissue MiniPrep Kit according to the standard manufacturer's protocol. The universal primer pair LCO1490 and HCO2198 (Folmer et al. 1994) was used to amplify a fragment of the mitochondrial gene cytochrome oxidase I (COI). PCR amplifications were carried out using $12.5 \mu \mathrm{l}$ of OneTaq QuickLoad Master Mix (New England BioLabs), $9.5 \mu$ of molecular biology grade water, $0.50 \mu 1$ of

Peer) reviewing PDF | (2020:05:48929:2:0:NEW 7 Sep 2020) 
184 forward and reverse primer $(10 \mu \mathrm{M}), 1 \mu \mathrm{l}$ of $1 \%$ bovine serum albumin (BSA) and $1 \mu 1$ of template 185 DNA to make up a total reaction volume of $25 \mu \mathrm{l}$. Thermal cycling conditions were as follows for 186 M. elityeni and M. sherlockae n. sp.: initial denaturation at $95^{\circ} \mathrm{C}$ for 3 minutes, followed by 35 187 cycles of $94{ }^{\circ} \mathrm{C}$ for 20 seconds, $45^{\circ} \mathrm{C}$ for 30 seconds and $72{ }^{\circ} \mathrm{C}$ for 1 minute, followed by a final 188 extension time at $72^{\circ} \mathrm{C}$ for 5 minutes. Amplicons were Sanger sequenced at the Central Analytical 189 Facility at Stellenbosch University using just the forward primer (LCO1490). Quality control was 190 performed on sequences to check for any sequencing errors using BioEdit (v7.2.6) (Hall 1999).

191

192

193

194

195

196

197

198

199

200

201

202

203

204

205

206

207

208

209

210

211

212

213

214

215

216

217

218

219

220

221

222

223

224

225

226

227

228

\section{Phylogenetic and species delimitation methods}

The COI sequences were edited, trimmed, and aligned with ClustalW (Thompson et al. 1994) using multiple alignment methods in BioEdit (v7.2.6). Several species belonging to the Marphysa genus were included in the analysis for comparison together with seven other species from different genera within the Eunicidae and one species from Onuphidae as they were used as outgroups to root the tree (see Table 1). DnaSP v5 (Librado \& Rozas 2009) was used to generate a nexus file for subsequent analysis. PAUP (Swafford 2003) and MrModelTest v2.3 (Nylander 2004) were used to calculate the best fit model of evolution for the data set using the Aikaike Information Criterion (AIC). Bayesian inference (BI) was used to reconstruct phylogenetic relationships using the best fit model SYM $+\mathrm{G}$ in MrBayes 3.1.2 (Ronquist et al. 2012). The trees were calculated using 4 Markov Chains of 5 million generations sampled simultaneously with every 1000 th tree sampled. A 50\% majority-rule consensus tree with posterior probability support was constructed by discarding the first $25 \%$ of trees as burn-in. Tracer v1.5 (Rambaut \& Drummond 2009) was used to investigate the convergence of runs by analysing the average standard deviation of split frequencies $(\leq 0.01)$. The mixing quality of all parameters was verified by analyzing the plot of likelihood versus the sampled trees and the effective sample sizes (ESS > 200), of which both criteria were satisfied. FigTree v1.4.4 (Rambaut 2013) was used to visualize trees. A Maximum Likelihood tree was computed in MEGA X (Kumar et al. 2018) and was run for 500 bootstrap replicates using the best-fit model of evolution, GTR, that was calculated in the same program.

A Newick formatted phylogenetic tree generated using FigTree v1.4.4 from the previous analysis was used as input for the Bayesian implementation of the Poisson tree process (bPTP) (Zhang et al. 2013) model for species delimitation using the online webserver https://species.hits.org/. The tree was rooted and run for 500,000 MCMC generations, with thinning set to 100 and burn-in and seed set to 0.1 and 123 , respectively. The convergence of MCMC chains was visually checked on the maximum likelihood plot generated by the online server.

MEGA X was used to calculate the interspecific genetic distances between species using the Kimura 2-parameter (K2P) model with complete deletion of gaps and run for 500 bootstrap replicates.

\section{Results}

Thorough morphological comparisons indicate that M. macintoshi and M. depressa do not occur in South Africa. Instead, M. durbanensis (type locality: South Africa), which was previously synonymized with M. macintoshi (type locality: Tanzania/Zanzibar) (Day, 1967) has been found to differ from the latter species with regards to the shape of the prostomium, anterior postchaetal 
229

230

231

232

233

234

235

236

237

238

239

240

241

242

243

244

245

246

247

248

249

250

251

252

253

254

255

256

257

258

259

260

261

262

263

264

265

266

267

268

269

270

271

272

273

lobes, pectinate chaetae, and the shape and distribution of branchiae throughout the length of the body. As a result, we here consider $M$. durbanensis as a valid species.

Moreover, specimens initially identified as M. depressa (type locality: New Zealand) in South Africa were a misidentification and instead represents a new species to science, here named M. sherlockae n. sp. Morphological comparisons reveal that $M$. sherlockae n. sp. differs from $M$. depressa in the shape and distribution of compound chaetae, the shape of postchaetal lobes, and the maximum number of branchial filaments. COI sequences of $M$. depressa were not available from its type locality and could not be compared with sequences of M. sherlockae n. sp. Nonetheless, $M$. sherlockae n. sp. forms an independent phylogenetic clade with high posterior probability and maximum likelihood support (Fig. 2) and genetically differs from other Marphysa species included in the phylogenetic analysis by $18-25 \%$, confirming that it is a separate species. Additionally, results from the bPTP analysis supported $M$. sherlockae n. sp. as a single independent species (BS>0.95) ( $\mathrm{S} 1$, supplementary information). M. sherlockae n. sp. is phylogenetically closest to Marphysa californica Moore, 1909, and Marphysa brevitentaculata, but the clade is poorly supported. Nonetheless, all three species genetically differ from each other by $18-20 \%$.

Marphysa haemasoma is a valid species. The examination of type materials allowed us to confirm that $M$. haemasoma differs from $M$. sanguinea in the shape of the postchaetal lobe in anterior chaetigers and subacicular hooks, the maximum number of branchial filaments and in the distribution of the swollen base of ventral cirri. Furthermore, types of $M$. elityeni only differ from those of M. haemasoma in size-related features, such as the length of prostomial appendices, and where branchiae and ventral cirri with a swollen base start. For these reasons, and in view of the principle of priority (ICZN 1999, Arts. 23), we consider Marphysa haemasoma a senior synonym of $M$. elityeni. Furthermore, M. haemasoma forms a well-supported phylogenetic clade independent of the M. sanguinea clade (Fig. 2). The species are genetically different from each other by $20 \%$, with results from the bPTP analysis (S1 supplementary information), confirming their separation as independent species $(\mathrm{BS}>0.95)$. Thus, these species are not synonymous.

\section{Systematics}

Order EUNICIDA Dales, 1962

Family EUNICIDAE Berthold, 1827

Genus Marphysa Quatrefages, 1865

Marphysa durbanensis Day, 1934

Figures 3, 4A, 5

Marphysa durbanensis Day, 1934:51-53, text-fig. 10.

Marphysa macintoshi - Day 1967:378 (non Crossland, 1903); Day 1974:59; Branch et al. 2016:68-69, P1. 26, Fig. 26.6.

Material examined. Type material: Lectotype designated here BMNH 1934.1.19.166, Durban, South Africa, 1933, coll. JH. Day. One paralectotype BMNH 1934.1.19.166 designated here, same information as lectotype. 
274 Comparative material examined. Marphysa macintoshi, syntypes, three specimens, BMNH 275 1924.3.1.22-3, slide BMNH.1924.3.1.22A, Zanzibar, Africa, 1901-1902, by digging in sand 276 between intertidal on both east and west coasts of Zanzibar (syntype 1 incomplete specimen with 277262 chaetigers, L10: $8.1 \mathrm{~mm}$, W10: $2.7 \mathrm{~mm}$; syntype 2 incomplete specimen with 106 chaetigers, 278 L10: $5.3 \mathrm{~mm}$, W10: $3 \mathrm{~mm}$; syntype 3 incomplete specimen with 160 chaetigers, L10: $7.8 \mathrm{~mm}$, 279 W10: $3 \mathrm{~mm}$ ).

280

281

282

283

284

285

286

287

288

289

290

291

292

293

294

295

296

297

298

299

300

301

302

303

304

Description. Lectotype complete, ventrally dissected from peristomium until chaetiger 9, with 380 chaetigers, $\mathrm{L} 10=14 \mathrm{~mm}, \mathrm{~W} 10=3.6 \mathrm{~mm}, \mathrm{TL}=305 \mathrm{~mm}$. Last 48 chaetigers regenerating. Anterior region of body with convex dorsum and flat ventrum; body depressed from chaetiger 7 , widest at chaetiger 24, tapering after chaetiger 37.

Prostomium bilobed, $1.7 \mathrm{~mm}$ long, $2.5 \mathrm{~mm}$ wide; lobes anteriorly rounded; median sulcus shallow dorsally (Fig. 3A), deep ventrally (Fig. 3B). Prostomial appendages in a semicircle, median antenna isolated by a gap. Palps reaching middle of first peristomial ring; lateral antennae reaching middle of second peristomial ring; median antenna broken, in paralectotype reaching middle of first chaetiger. Palpophores and ceratophores ring-shaped, short, thick; palpostyles and ceratostyles tapering, slender. Eyes not observed.

Peristomium ( $2.7 \mathrm{~mm}$ long, $3 \mathrm{~mm}$ wide) longer and wider than prostomium, first ring twice as long as second ring; separation between rings distinct on all sides (Fig. 3A-C). Ventral anterior edge of peristomium longer than dorsal, remaining features ventrally distorted by the dissection (Fig. 3B-C).

Maxillary apparatus with $\mathrm{MF}=1+1,5+6,6+0,4+8,1+1$ (Fig. 3D). MI 3.1 times longer than maxillary carriers. MI forceps-like, MI 4.6 times longer than closing system (Fig. 3D-E); ligament between MI and MII sclerotized. MII wider than rest of maxillae, with triangular teeth; MII 3.6 times longer than cavity opening oval (Fig. 3D-E); ligament present between MII-MIII and right MII-MIV slightly sclerotized (Fig. 3E). MIII with triangular teeth; with rectangular attachment lamella, situated in the centre of ventral edge of maxilla, slightly sclerotized (Fig. 3D-E). Left MIV with two left-most teeth larger; attachment lamella semicircle, slender, better developed in central portion, situated 1/2 along anterior edge of maxilla. Right MIV with teeth of equal size; attachment lamella semicircle, slender, better developed in central portion, situated $2 / 3$ along anterior edge of maxilla, sclerotized (Fig. 3D-E). MV square, with a short triangular tooth. Mandibles dark; missing calcareous cutting plates; sclerotized cutting plates brown, with 20 growth rings (Fig. 3F).

Branchiae pectinate with up to 11 long filaments at around $64-80 \%$ of the body, present from chaetigers 28L-29R to 370 (Fig. 3J-K). First pair and last 10 with one filament; reach the maximum 10 or 11 filaments in chaetigers 241L-307L (Fig. 4A). Branchial filaments longer than dorsal cirri except in first five and last seven branchiae.

First two parapodia smallest; best developed in chaetigers 6-26, following ones becoming gradually smaller. Notopodial cirri conical in anterior-median chaetigers, digitiform in posterior ones; longer than ventral cirri in anterior chaetigers, of similar length in posterior ones; best developed in chaetigers 3-30, following ones gradually smaller (Fig. 3G-K). Prechaetal lobes short, as transverse fold in all chaetigers (Fig. 3G-K). Chaetal lobes rounded in all chaetigers, shorter than postchaetal lobes in anterior region, longer than the other lobes in median-posterior region; with aciculae emerging dorsal to midline (Fig. 3G-K). Postchaetal lobes well developed in first 40 chaetigers; digitiform in first five chaetigers, rounded from chaetiger 6; progressively smaller from chaetiger 22; from chaetiger 41 inconspicuous (Fig. 3G-K). Ventral cirri bluntly

Peer) reviewing PDF | (2020:05:48929:2:0:NEW 7 Sep 2020) 
320

321

322

323

324

325

326

327

328

329

330

331

332

333

334

335

336

337

338

339

340

341

342

343

344

345

346

347

348

349

350

351

352

353

354

355

356

357

358

359

360

361

362

363

364

365

conical in first five chaetigers; in chaetigers 6 to 355 with a short oval base and digitiform tip; conical from chaetiger 356, gradually reducing in size (Fig. $3 \mathrm{G}-\mathrm{K})$.

Aciculae blunt, reddish along most of their length, amber on the distal tip (Fig. 3G-K). First eight chaetigers with three aciculae; in chaetigers 9-18 with four aciculae; in chaetigers 1944 with three or four aciculae; in chaetigers 45-124 with two aciculae; from chaetiger 125 with only one acicula.

Limbate chaetae of two lengths in same chaetiger, dorsalmost longer; reduced in number around chaetiger 30. Five types of pectinate chaetae, anterior chaetigers: thin, narrow isodont with long and slender teeth, 3-4 pectinate, with up to 14-15 teeth (Figs 3L, 5A); median and posterior chaetigers: thin, wide isodont with short and slender teeth, 4-5 pectinate, with up to 23-24 teeth (Figs 3M, 5B); thick, wide isodont with short and thick teeth, 1-2 pectinate, with up 19 teeth (Figs $3 \mathrm{~N}, 5 \mathrm{C}$ ); and thick wide anodont with short and slender teeth, 1-2 pectinate, with 12 teeth (Figs $3 \mathrm{O}, 5 \mathrm{D})$; posterior chaetigers: thick, wide anodont with long and thick teeth, 1-2 pectinate, with up to 17 teeth. Compound spinigers present in all chaetigers, in anterior-median chaetigers with blades of two lengths, shorter ones more abundant (Fig. 3P). Subacicular hooks unidentate, amber, present from chaetiger 46, one or two per chaetiger, with continuous distribution (Fig. 3Q).

Pygidium with dorsal pair of anal cirri as long as last eight chaetigers; ventral pair short, as long as last two chaetigers.

Variations. Material examined $\mathrm{L} 10=12-14 \mathrm{~mm}, \mathrm{~W} 10=3.6-4 \mathrm{~mm}$, TChae $=322-380$. Palps reaching middle of first or second peristomial ring; lateral antennae reaching middle of second peristomial ring or first chaetiger; median antenna reaching first chaetiger. The maxillary variations are MII 5-6+6-8, MIII 6 , MIV 3-4+6-8. The proportion of maxillary apparatus varies as follows: MI are 3.1-3.2 times longer than maxillary carriers; MI are 4.6-5.3 times longer than closing system; MII are 3.5-3.6 times longer than length of cavity opening. Branchiae from chaetigers 28-32 to 10-13 chaetigers before pygidium. Maximum number of branchial filaments varied from 11 to 12 . Postchaetal lobe well developed in the first 40 chaetigers. Ventral cirri with a swollen base from chaetigers $4-5$ to 25 chaetigers before pygidium. Start of subacicular hooks in chaetigers $46-47$.

Habitat. Day (1934) does not provide information about the specific substrate, although he did clarify that the collection was between the tidemarks in Durban Bay and Umkomaas.

Distribution. Day (1934) recorded this species from Durban Bay and Umkomaas in KwaZuluNatal, South Africa.

Remarks. The original description of Marphysa durbanensis provides a variation of the two specimens collected that matches with the specimens deposited in the BMNH. Day (1934) described almost colorless eyes, but they were not observed in this study. Possibly the color has faded due to the long-term preservation of the specimens. The best-preserved specimen is herein selected as a lectotype to fix the species definition (ICZN 1999, Arts. 74.1, 74.7.3), whereas the other is considered a paralectotype (ICZN 1999, Art. 74F).

Day (1934) considered M. durbanensis different from morphologically similar species such as M. simplex Crossland, 1903 (= M. teretiuscula), and M. acicularum when he described the species. However, in his monograph of the polychaetes from South Africa, the author considered M. durbanensis a junior synonym of M. macintoshi without making any reference to this 
366

367

368

369

370

371

372

373

374

375

376

377

378

379

380

381

382

383

384

385

386

387

388

389

390

391

392

393

394

395

396

397

398

399

400

401

402

403

404

405

406

407

408

409

410

nomenclatural action (Day 1967, page 378). Herein, apparent differences were found between the species. Marphysa durbanensis (L10: $14 \mathrm{~mm}$ ) has a bilobed prostomium, the branchiae are pectinate and start from chaetigers 28-32, the postchaetal lobe is digitiform in first four chaetigers, and there are five types of pectinate chaetae; while in M. macintoshi (L10: $4.5 \mathrm{~mm}$ ) the prostomium is unilobed with a shallow median sulcus at the anterior edge, the branchiae are palmate with a short button-shaped branchial stem and start from chaetiger $32-47$, the postchaetal lobe is conical in the first four chaetigers, and there are only three types of pectinate chaetae. Due to these morphological differences, $M$. durbanensis is considered a valid species.

Marphysa durbanensis resembles $M$. haemasoma (see below) by the presence of compound spinigers distributed in all chaetigers; however, M. durbanensis has more teeth in MII (5-6+6-8), digitiform postchaetal lobes in first four chaetigers, five types of pectinate chaetae, and the subacicular hook with a continuous distribution even in bigger specimens. However, $M$. haemasoma has fewer teeth in MII (4+4). The postchaetal lobe is ovoid in the first four chaetigers. There are only four types of pectinate chaetae, and the subacicular hook has a discontinuous distribution in small specimens.

Marphysa durbanensis resembles M. victori Lavesque, Daffe, Bonifacio \& Hutchings, 2017, M. hongkongensa Wang, Zhang \& Qiu, 2018, M. leidii Quatrefages, 1866, M. parishii Baird, 1869 and $M$. teretiuscula by the presence of five types of pectinate chaetae; however, $M$. durbanensis has a digitiform postchaetal lobe in the first four chaetigers, and the subacicular hook is amber, while $M$. teretiuscula has an ovoid postchaetal lobe in the first four chaetigers, and the subacicular hook is reddish basally and translucent in the distal region. Also, M. leidii has a conical postchaetal lobe in the first chaetigers. Otherwise, M. durbanensis has long branchial filaments, and the branchiae are pectinate; while for $M$. hongkongensa, the branchial filaments are short, and the branchiae are pectinate and palmate with a short button-shaped branchial stem in some regions of the body. On the other hand, in M. durbanensis (L10: $14 \mathrm{~mm}$ ), the eyes are present, and the branchiae start in chaetigers 28-32; while M. victori (L10: 6.3-7.9 mm) lacks eyes, and the branchiae start in chaetiger 36. Finally, M. durbanensis has up to 11-12 branchial filaments while M. leidii (L10: 10.7-17 mm) and M. parishii (L10: $17.2 \mathrm{~mm}$ ) only have 4 to 6 filaments.

\section{Marphysa haemasoma Quatrefages, 1866 Figures 4B, 6-7}

Marphysa haemasoma Quatrefages, 1866:334-335; Grube 1870:299.

Marphysa sanguinea - Marenzeller 1888:11, Fauvel 1902:61; Day 1967:378 (non Montagu, 1813); Day 1974:59.

Marphysa sanguinea haemasoma Willey, 1904:263, P1.13, Fig.15

Marphysa elityeni Lewis \& Karageorgopoulos, 2008:279-281, Figs. 1-2, Table 1, 2, 3; Branch et al. 2016:68-69, P1. 26, Fig. 26.5.

Material examined. Type material: Holotype Marphysa haemasoma MNHN type 613, Cape of Good Hope, South Africa. Additional material: Five incomplete specimens SAM-A090272, SAMA090273, SAM-A090274, SAM-A090275, SAM-A090317, Kommetjie, South Africa from sand burrows under boulders at fringing intertidal zone, coll. A.N. du Toit, 10 Mar 2017, 18 19'40.7"E $34^{\circ} 09^{\prime} 33.0^{\prime \prime} \mathrm{S}$.

Peer) reviewing PDF | (2020:05:48929:2:0:NEW 7 Sep 2020) 
411 Comparative material examined. Holotype Marphysa elityeni SAM-A21478, Cape of Good 412 Hope, South Africa. Eight paratypes of Marphysa elityeni BMNH 2007.69, SAM-A21479, SAM413 A21480, SAM-A21481, Buffels Bay in the Cape of Good Hope, South Africa, 15 Sep 2004, 414 18²9'27" E 34²1'6" S. Neotype Marphysa sanguinea BMNH 1867.1.7.24, Polperro, Cornwall, 415 in mud and gravel at low water mark, coll. Laughrin, Redet. P. Hutchings (2 specimens from this 416 lot), Desig. P. Hutchings (Neotype complete specimen with 286 chaetigers, L10: $16.7 \mathrm{~mm}$, W10:

Description. Holotype complete, gravid female, with 322 chaetigers, L10 $=12.3 \mathrm{~mm}, \mathrm{~W} 10=7 \mathrm{~mm}$ $\mathrm{TL}=309 \mathrm{~mm}$. Anterior region of the body with convex dorsum and flat venter; body depressed from chaetiger 5 , widest at chaetiger 25, tapering after chaetiger 41 .

Prostomium bilobed, $2.8 \mathrm{~mm}$ long, $4 \mathrm{~mm}$ wide; lobes anteriorly rounded; median sulcus dorsally shallow (Fig. 6A), ventrally deep (Fig. 6B). Prostomial appendages in a semicircle, median antenna isolated by a gap. Palps reaching first chaetiger; lateral and median antennae reaching second chaetiger. Palpophores and ceratophores ring-shaped, short, thick; palpostyles and ceratostyles tapering, slender. Eyes colorless, as a scar between palps and lateral antennae.

Peristomium ( $2.8 \mathrm{~mm}$ long, $6.3 \mathrm{~mm}$ wide) wider than prostomium; first ring three times as long as second ring, separation between rings distinct only dorsally and ventrally (Fig. 6A-C). Ventral region of the first ring with a slight central depression in anterior edge (Fig. 6B).

Maxillary apparatus with $\mathrm{MF}=1+1,4+4,5+0,3+7,1+1$ (Fig. 6D). MI 3 times longer than maxillary carriers. MI forceps-like, MI 4 times longer than closing system (Fig. 6D-E); ligament between MI and MII, sclerotized. MII with triangular teeth, right anterior teeth broken; MII 3.6 times longer than cavity opening (Fig. 6D-E); ligament present between MII-MIII and right MIIMIV slightly sclerotized (Fig. 6E). MIII with triangular teeth; with rectangular attachment lamella, situated only in the centre of right edge of maxilla, slightly sclerotized (Fig. 6D-E). Left MIV with all teeth of similar size; attachment lamella semicircle, wide, better developed in right portion, situated $2 / 3$ of anterior edge of maxilla. Right MIV with lateral larger teeth; attachment lamella semicircle, wide, better developed in central portion, situated $2 / 3$ of anterior edge of maxilla, sclerotized (Fig. 6D-E). MV square, with a short triangular tooth. Mandibles dark; with calcareous cutting plates present and sclerotized cutting plates brown, with nine growth rings (Fig. 6F).

Branchiae pectinate with up to six long filaments for around $20-54 \%$ of the body, present from chaetigers $26 \mathrm{~L}-27 \mathrm{R}$ to $308 \mathrm{~L}-311 \mathrm{R}$ (Fig. 6I-J). First two and last 13 pairs with one filament; with six filaments in chaetigers $79 \mathrm{~L}$ to $173 \mathrm{~L}$ (Fig. 4B). Branchial filaments longer than dorsal cirri except in first two and last branchiae.

First two parapodia smallest; best developed in chaetigers $7-40$, following ones gradually becoming smaller. Notopodial cirri conical in all chaetigers; of similar length as ventral cirri in anterior and posterior chaetigers, shorter than ventral cirri in median chaetigers; best developed in chaetigers 4-37, following ones gradually smaller (Fig. 6G-K). Prechaetal lobes short, as transverse folds in all chaetigers (Fig. 6G-K). Chaetal lobes in first 37 chaetigers rounded, shorter than postchaetal lobe in anterior region, with aciculae emerging dorsal to midline; from chaetiger 38 triangular, longer than other lobes in median-posterior chaetigers (Fig. 6G-K). Postchaetal lobes well developed in first 60 chaetigers; ovoid in first six chaetigers, rounded in chaetigers 79, auricular from chaetiger 10, progressively smaller from chaetiger 35; from chaetiger 61 inconspicuous (Fig. 6G-K). Ventral cirri digitiform in first three chaetigers; in chaetiger four to last chaetiger with a short oval base and digitiform tip (Fig. 6G-K). 
456

457

458

459

460

461

462

463

464

465

466

467

468

469

470

471

472

473

474

475

476

477

478

479

480

481

482

483

484

485

486

487

488

489

490

491

492

493

494

495

496

497

498

499

500

501
Aciculae blunt, reddish along most of their length, amber on distal tip (Fig. 6G-K). First 10 chaetigers with three aciculae; in chaetigers 11-77 with three or four; in chaetigers 78-161 with three; in chaetigers 162-322 with two or three.

Limbate chaetae of two lengths in same chaetiger, dorsalmost longer, reduced in number around chaetiger 24 . Four types of pectinate chaetae; in anterior chaetigers: thin, narrow isodont with long and slender teeth, with 2-3 pectinate, with up to 17 teeth (Fig. 6L); median-posterior chaetigers: thick, wide isodont with short and slender teeth, with 6-7 pectinate, with up to 17 teeth (Fig. 6M); posterior chaetigers: thick, wide anodont with short and slender teeth, with 6-7 pectinate, with up to 13-14 teeth (Fig. $6 \mathrm{~N}$ ), and thick, wide anodont with long and thick teeth, with 1-2 pectinate, with up to 10 teeth (Fig. 6O). Compound spinigers present in all chaetigers, with blades of two sizes in the same chaetiger (Fig. 6P), shorter slightly more abundant than longer blade. Subacicular hooks absent; in paratype of $M$. elityeni $(\mathrm{L} 10=9.3 \mathrm{~mm})$ subacicular hook bidentate, translucent, present only in regenerating chaetigers, one per chaetiger; with triangular teeth, distal tooth smaller than proximal, directed upward; proximal tooth triangular, directed laterally (Fig. 6Q).

Pygidium with dorsal pair of anal cirri broken; ventral pair as long as last chaetiger.

Variations. Material examined $\mathrm{L} 10=9.3-20.1 \mathrm{~mm}, \mathrm{~W} 10=6.2-14.5 \mathrm{~mm}$, TChae $=194-486$. Palps reaching second peristomial ring or first chaetiger; lateral antennae reaching first or second chaetiger; median antenna reaching first or middle of second chaetiger. The maxillary variations are MII 4+4, MIII 3-5, MIV 3-4+6-7. The proportion of maxillary apparatus varies as follows: MI are 2.6-3 times longer than maxillary carriers; MI are 4.1-4.6 times longer than closing system; MII are 4-4.3 times longer than cavity opening. Branchiae from chaetigers 26-37 to 10 chaetigers before pygidium. Maximum number of branchial filaments varied from six to 10. Postchaetal lobe well developed in first 57-60 chaetigers. Ventral cirri with a swollen base from chaetigers 3-6 to last chaetigers.

DNA barcode. Type locality: Kommetjie, Western Cape, South Africa (MB-A090272) (GenBank accession number: MN067877) (Simon et al. unpublished data). 577 bp fragment isolated with universal mitochondrial cytochrome oxidase subunit 1 gene, primer pair: LCO1490, HCO2198 (Folmer et al. 1994).

Habitat. Very common in the boulder fields at the lower intertidal zones of sheltered bays, and in rock pools. Worms can be found under rocks in sand burrows up to $1 \mathrm{~m}$ deep.

Distribution. Table Bay to Buffels Bay, Cape Point, Western Cape South Africa (Quatrefages 1866; Lewis \& Karageorgopoulos 2008). Branch et al. (2016) recorded this species to occur from Namibia in southwest Africa to East London in South Africa. Simon et al. (unpublished data) recorded this species from Melkbosstrand to Knysna in the Western Cape and therefore falls within the currently accepted distribution range of this species according to Branch et al. (2016). However, the records from Namibia have not been verified and may also represent an overlooked indigenous species of that region and therefore should be revised.

Remarks. Specimens of $M$. haemasoma were previously redescribed by Grube (1870) and then identified as $M$. sanguinea after von Marenzeller (1888) synonymized M. haemasoma with $M$. sanguinea due to similarities in morphology and habitat observed in the specimens from the Cape 
502 of Good Hope. Later, Lewis \& Karageorgopoulos (2008) realized that specimens from this region 503 had been misidentified as M. sanguinea, which led to the description of Marphysa elityeni Lewis 504 \& Karageorgopoulos, 2008. However, Lewis \& Karageorgopoulos (2008) overlooked M. 505 haemasoma.

506 After the comparison between the type material of M. haemasoma and M. elityeni we found 507 stable similarities in the shape of the prostomium (Figs 6A, 7A), the proportions of maxillary apparatus, the number of teeth per maxilla and the shape of the maxillary apparatus (Figs 6D-E, $7 \mathrm{~B}-\mathrm{C}$ ), the form of the branchiae in median-posterior chaetigers (Figs 6J, 7F), the shape of the dorsal cirri, ventral cirri, and postchaetal lobe in anterior chaetigers (Figs 6G-H, 7D-E, G-H), as well as, the presence of the same type of pectinate chaetae (Figs 6M-N, 7I-J) and compound chaetae, and the form and coloration of subacicular hook (Figs 6Q, 7K). Some differences were related to the size dependence of characters, like the beginning of the branchiae, the number of filaments, and the development of the postchaetal lobe (M. elityeni material L10: 9.3-18.5 mm, branchiae from chaetiger 27-37, number of filaments from 6-10, ending of the postchaetal lobe from chaetiger 33-82; M. haemasoma material L10: $12.3 \mathrm{~mm}$, branchiae from chaetiger 26, number of filaments reached 6, ending of the postchaetal lobe in chaetiger 60).

Marphysa haemasoma (L10: $9.3-18.5 \mathrm{~mm}$ ) is considered a different species from $M$. sanguinea (L10:11.5-20.4) because the former has up to 10 branchial filaments, and ovoid postchaetal lobes in anterior chaetigers; whereas the latter has 9-18 branchial filaments, and digitiform postchaetal lobes in anterior chaetigers. Moreover, in M. haemasoma the swollen base of the ventral cirri continues until the last chaetigers, and the subacicular hook is translucent; while in $M$. sanguinea the swollen base of the ventral cirri ends between 8-18 chaetigers before the pygidium, and the subacicular hook is reddish basally and translucent distally.

Marphysa haemasoma resembles M. aegypti Elgetany, El-Ghobashy, Ghoneim \& Struck, 2018, M. fauchaldi Glasby \& Hutchings, 2010, M. gravelyi Southern, 1921, M. nobilis Treadwell, 1917, M. teretiuscula (Schmarda, 1861) and M. tripectinata Liu, Hutchings \& Sun, 2017 by the presence of the ovoid postchaetal lobes; however, M. haemasoma has subacicular hooks that are completely translucent, while M. nobilis, M. teretiuscula, and M. tripectinata have subacicular hooks that are reddish at the base and translucent in the distal region. Furthermore, M. haemasoma has four types of pectinate chaetae, while $M$. fauchaldi and M. gravelyi have only three types. Additionally, when present in $M$. haemasoma, subacicular hooks (in regenerating chaetigers) are bidentate, while $M$. aegypti bears unidentate subacicular hooks (Martin et al. 2020). Moreover, $M$. haemasoma has fewer teeth in MII and MIII (4+4, 4-5+0), while M. gravelyi has more teeth in the same plates (MI 8+7, MII 8+0). Finally, M. haemasoma has long branchial filaments, while in $M$. fauchaldi, the branchial filaments are short.

Type material of $M$. elityeni was collected from Buffels Bay, Cape Peninsula (Lewis \& Karageorgopoulos 2008), which is $\sim 58.4 \mathrm{~km}$ away from Table Bay where type material of $M$. haemasoma was collected (Fig. 1). Additionally, Kommetjie, where the fresh materials examined and sequenced in this study were collected, is near both Buffels Bay $(\sim 29.4 \mathrm{~km})$ and Table Bay $(\sim 43$ $\mathrm{km})$. Thus, all these collections fall within the type region of the original collected material from Table Bay (Fig. 1).

\author{
Marphysa sherlockae n. sp. \\ urn:Isid:zoobank.org:act:2D2AC893-C074-46CC-B731-F0D632C66836 \\ Figures 4C, 8-10
}


548

549

550

551

552

553

554

555

556

557

558

559

560

561

562

563

564

565

566

567

568

569

570

571

572

573

574

575

576

577

578

579

580

581

582

583

584

585

586

587

588

589

590

591

592

593

Marphysa depressa - Day 1953:434, text-figs. 5 n, p; 1967:395-396, Figs. 17.5 n-t (non Schmarda, 1861); Day 1974:59; Branch et al. 2016:68-69, P1. 26, Fig. 26.8.

Material examined. Type material: Holotype BMNH 1963.1.84, Langebaan Lagoon, South Africa, coll. J.H. Day. Paratype, one specimen BMNH 1952.5.10.7. Paratype, two specimens SAMC-A089089 and SAMC-A089090), Strand, False Bay, South Africa, 34 06'57.9" S, 1849'18.1” E, coll. J. Kara, 20 March 2019, det. J. Kara. Additional material: two specimens BMNH XXXX, same data as holotype. One incomplete specimen SAMC-A20578, Langebaan lagoon, South Africa, coll. UCT ecological survey, 24 April 1949, det. J.H. Day. One complete specimen SAMC-A60425, Langebaan Lagoon, South Africa, coll. UCT ecological survey, 24 April 1949, det. D. Clarke. Two complete specimens, SAMC- A089091 and SAMC- A089092), Strand, False Bay, South Africa, 3406'57.9” S, 1849'18.1” E, coll. J. Kara, 20 March 2019, det. J. Kara.

Comparative material examined. Syntypes, two specimens, Marphysa depressa NHM XXX, New Zealand, Port of Auckland, coll. Schmarda (syntype 1 complete specimen with 328 chaetigers, L10: 9.5, W10: 4 mm; syntype 2 complete specimen with 132 chaetigers, L10: $9.5 \mathrm{~mm}$, W10: $4.8 \mathrm{~mm})$.

Description. Holotype complete, with 208 chaetigers, L10 $=6.6 \mathrm{~mm}, \mathrm{~W} 10=1.7 \mathrm{~mm}, \mathrm{TL}=67 \mathrm{~mm}$. Anterior region of body with convex dorsum and flat venter, body depressed from chaetiger 6 , widest at chaetiger 38, tapering after chaetiger 112 .

Prostomium bilobed, $1 \mathrm{~mm}$ long, $1.1 \mathrm{~mm}$ wide; lobes frontally oval; with median sulcus dorsally shallow (Fig. 8A), ventrally sulcus deep (Fig. 8B). Prostomial appendages in a semicircle, median antenna isolated by a gap. Palps reaching first chaetiger; lateral antennae reaching second chaetiger; median antenna reaching middle of second chaetiger. Palpophores and ceratophores ring-shaped, short, thick; palpostyles and ceratostyles tapering, slender. Eyes as a brown line, between palps and lateral antennae.

Peristomium (1.1 $\mathrm{mm}$ long, $3.2 \mathrm{~mm}$ wide) wider than prostomium, first ring twice as long as second, separation between rings distinct on all sides (Fig. 8A-C). Ventral region of the first ring with a slight central depression in anterior edge (Fig. 8B).

Maxillary apparatus with $\mathrm{MF}=1+1,3+5,5+0,4+8,1+1$ (Fig. 6D). MI 2.3 times longer than maxillary carriers. MI forceps-like, MI 4.3 times longer than the closing system; ligament between MI and MII, slightly sclerotized (Fig. 8D-E). MII with recurved teeth; MII 5 times longer than cavity opening oval (Fig. 8D-E); ligament present between MII and MIII and right MIV slightly sclerotized (Fig. 8E). MIII with blunt teeth; with rectangular attachment lamella, situated in the anterior of right edge of maxilla, slightly sclerotized (Fig. 8D-E). Left MIV with left-most tooth larger; attachment lamella semicircle, wide, better developed in right portion, situated along anterior edge of maxilla (Fig. 8D-E). Right MIV with right-most tooth larger; attachment lamella semicircle, wide, better developed in central portion, situated along anterior edge of maxilla (Fig. 8D-E). MV square, with a short-rounded tooth. Mandibles dark; missing calcareous cutting plates, sclerotized cutting plates brown, with 10 growth rings (Fig. 8F).

Branchiae palmate with a short button-shaped branchial stem, with up to two long filaments, present from chaetigers $28 \mathrm{R}-37 \mathrm{~L}$ to $195 \mathrm{~L}-196 \mathrm{R}$ (Fig. 8J-K). One filament in chaetigers $28 \mathrm{~L}$ and $31 \mathrm{~L}-45 \mathrm{~L}$; without filament in chaetigers $29 \mathrm{~L}-30 \mathrm{~L}$; two filaments in chaetigers $46 \mathrm{~L}-$ 170L; one filament in chaetigers171L-196L (Fig. 4C). Branchial filaments longer than dorsal cirri.

Peer] reviewing PDF | (2020:05:48929:2:0:NEW 7 Sep 2020) 
594

595

596

597

598

599

600

601

602

603

604

605

606

607

608

609

610

611

612

613

614

615

616

617

618

619

620

621

622

623

624

625

626

627

628

629

630

631

632

633

634

635

636

637

638

639

First two parapodia smallest; best developed in chaetigers 6-42, following ones becoming gradually smaller. Notopodial cirri conical in all chaetigers; longer than ventral cirri in anterior chaetigers, shorter in median chaetigers, of similar size in posterior ones; best developed in chaetigers 3-41, following ones gradually decreasing in size (Fig. 8G-K). Prechaetal lobes short. Chaetal lobes in first 29 chaetigers rounded, shorter than postchaetal lobe, with aciculae emerging dorsal to midline; from chaetiger 30 triangular, longer than other lobes (Fig. 8G-K). Postchaetal lobes slightly developed in first 24 chaetigers; triangular first 5 chaetigers, following ones auricular, progressively smaller from chaetiger eight; from chaetiger 25 inconspicuous (Fig. 8G$\mathrm{K})$. Ventral cirri conical in first six chaetigers; from chaetigers 7 to 138 with a short oval base and digitiform tip; conical from chaetiger 139, gradually smaller (Fig. 8G-K).

Aciculae blunt, reddish from base to most of its length, translucent on the distal tip (Fig. $8 \mathrm{G}-\mathrm{K})$. First five chaetigers with 2 aciculae; in chaetiger 6-10 with three aciculae; in chaetigers 11-73 with two aciculae; from chaetiger 74 with only one acicula.

Limbate chaetae of two lengths in same chaetiger, dorsal-most longer, reduced in number around chaetiger 13. Two types of pectinate chaetae; in anterior chaetigers: thin, narrow isodont with long and slender teeth, 1-2 per parapodium and up to 10-11 teeth (Figs 8L, 9A-C); in medianposterior chaetigers, thick, wide isodont with long and thick teeth, 4-5 per parapodium and up to 14 teeth (Figs 8M, 9D-E); anodont pectinate not observed. Compound spiniger chaetae present in all chaetigers, with blades of similar size in the same chaetiger (Fig. $8 \mathrm{~N}$ ), longer blades in medianposterior chaetigers. Compound falciger chaetae in anterior-median chaetigers, more abundant than compound spiniger in first 26 chaetigers; in anterior region blades of similar length $(56 \mu \mathrm{m}$, Fig. 80), with triangular teeth, both of similar size, proximal tooth directed laterally, distal directed upward; in median chaetigers with blades shorter $(38.5 \mu \mathrm{m})$ with teeth of similar shape. Subacicular hooks bidentate, reddish from base to most of its length, with translucent tip, starting from chaetigers $41 \mathrm{R}-42 \mathrm{~L}$, one per chaetiger, with continuous distribution; with blunt teeth, distal tooth smaller than proximal, both teeth directed upward (Fig. 8P); some chaetigers with subacicular hook unidentate with hoods.

Pygidium with dorsal pair of anal cirri as long as last seven chaetigers; ventral pair short, as long as the last chaetiger.

Variations. Material examined varied in the following features: $\mathrm{L} 10=3-6.6 \mathrm{~mm}, \mathrm{~W} 10=1.3-2.1$ $\mathrm{mm}$. Palps reaching second peristomial ring or first chaetiger; lateral antennae reaching middle of first or second chaetiger; median antenna reaching third or fourth chaetiger. Maxillary formula varies as follows: MII 3-4+4-5, MIII 5-6, MIV 3-4+7-8. The proportion of maxillary apparatus varies as follows: MI are 2.4-2.7 times longer than maxillary carriers; MI are 4.3-5 times longer than closing system; MII are 3-3.3 times longer than cavity opening. Branchiae from chaetigers 25-34. The maximum number of branchial filaments 2 . Postchaetal lobe well developed in first 17-91 chaetigers. Ventral cirri with a swollen base from chaetigers 3-7 to 70 chaetigers before pygidium. Falcigers present up to last chaetiger $(\mathrm{L} 10=3-6 \mathrm{~mm})$ or median region $(\mathrm{L} 10=6.1-66$ $\mathrm{mm})$. Start of subacicular hooks in chaetigers $28-43$.

Regression analyses indicated that there are no correlations between the start of the branchiae $\left(R^{2}=0.0702, p=0.26, n=11\right.$, Fig. 10$)$, the maximum number of branchial filaments $\left(R^{2}=\right.$ $0.000, p=0.00 \mathrm{n}=11$, Fig. 10$)$ or the start of the subacicular hooks $\left(\mathrm{R}^{2}=0.1307, \mathrm{p}=0.35, \mathrm{n}=11\right.$, Fig. 10) with the length to chaetiger 10 for this species. The chaetiger where the branchiae start does not follow a pattern regarding their growth but starts to emerge from chaetiger 20 to 30 (Fig. 8 , blue points). This same situation is repeated with emergence of subacicular hooks, starts 
640 between chaetiger 30 and 40 (Fig. 10, orange points). However, the number of filaments (2 641 filaments) seems to be fixed regardless of the size of the organism, a contrasting pattern with other 642 Marphysa species in which the number of filaments appears to increase with the length of the 643 specimen.

644 On the other hand, M. sherlockae n. sp. has similar characteristics to other species of 645 Marphysa where the presence of compound chaetae is size-dependent (Aiyar 1931; Pillai 1958; 646 Salazar-Vallejo \& Carrera-Parra 1998; Molina-Acevedo \& Carrera-Parra 2017; Molina-Acevedo 647 2018). Marphysa sherlockae n. sp. specimens with L10 $\leq 6 \mathrm{~mm}$ possess compound falcigers to the 648 last chaetiger. In this group of individuals, the number of falcigers per chaetiger decreased from 649 median to posterior region, which was more noticeable in specimens with L10 close to $6 \mathrm{~mm}$. 650 Additionally, specimens with L10 $>6 \mathrm{~mm}$ do not have falcigers in the posterior region. This 651 condition indicates that in the largest specimens of $M$. sherlockae $\mathbf{n}$. sp. falcigers will be lost, and 652 only compound spinigers will be observed, as demonstrated in M. gravelyi Southern, 1921, M. 653

654

655

656

657

658

659

660

661

662

663

664

665

666

667

668

669

670

671

672

673

674 borradailei Pillai, 1958 and M. brevitentaculata Treadwell, 1921.

Etymology: The species is named after Emma Sherlock, in recognition of her valuable work on the polychaete collections of BHNM.

DNA barcode: Type region: Strand, False Bay, Western Cape, South Africa (Museum number: SAMC-A089090) (GenBank accession number: MT840249). 577 bp fragment isolated with universal mitochondrial cytochrome oxidase subunit 1 gene, primer pair: LCO1490, HCO2198 (Folmer et al. 1994).

Habitat. Fringing rocky zones at low tide in sheltered bays. Worms can be found in rock crevices.

Type locality. Langebaan Lagoon, South Africa.

Distribution. Day $(1953 ; 1967)$ and Branch et al. (2016) recorded this species to occur in rocky coasts and estuaries from Saldanha Bay in the Western Cape to Durban in KwaZulu-Natal, South Africa.

Remarks. Day (1953) studied the material collected by himself and other members of the Zoology Department at the University of Cape Town during ecological surveys of the rocky coasts and estuaries in South Africa. The author identified some specimens as Marphysa depressa collected from localities such as East London, Bushman's Estuary, Still Bay, Cape Agulhas, and Langebaan

675 Lagoon due to the presence of compound spinigers and falcigers in the same chaetiger which is 676 similar to the New Zealand species. As a result, this was the first record of the species in South 677 Africa. Additionally, Day compared his material with a specimen collected from New Zealand by 678 Ehlers (1904), most likely to confirm his identification. However, thorough taxonomic revisions 679 revealed marked differences between the material from South African and New Zealand and led 680 us to conclude that the South African specimens belong to a new species named herein as 681

682

683

684

685 Marphysa sherlockae n. sp..

Marphysa sherlockae n. sp. differs from M. depressa in the chaetal distribution. For example, the former has compound spinigers in all chaetigers, and compound falcigers restricted to the median and posterior chaetigers; whereas in $M$. depressa, the compound falciger is present in all chaetigers, but the spinigers are only present in the anterior region. Also, M. sherlockae $\mathbf{n}$.

Peer] reviewing PDF | (2020:05:48929:2:0:NEW 7 Sep 2020) 
686

687

688

689

690

691

692

693

694

695

696

697

698

699

700

701

702

703

704

705

706

707

708

709

710

711

712

713

714

715

716

717

718

719

720

721

722

723

724

725

726

727

728

729

730

sp. has a triangular postchaetal lobe, while $M$. depressa has a digitiform postchaetal lobe. Furthermore, $M$. sherlockae n. sp. (L10: 5.7-6.6 mm) has only two branchial filaments, while $M$. depressa (L10: $9.5 \mathrm{~mm}$ ) has up to four filaments.

Marphysa sherlockae n. sp. resembles M. durbanensis and M. haemasoma by having compound spinigers. However, M. sherlockae n. sp. (L10: 5.7-6.6 mm) has two branchial filaments, triangular postchaetal lobe in anterior chaetigers, and ventral cirri with a swollen base ending 70 chaetigers before pygidium; whereas $M$. durbanensis (holotype, L10: $14 \mathrm{~mm}$ ) has 1112 branchial filaments, digitiform postchaetal lobes, and ventral cirri with a swollen base ending 25 chaetigers before pygidium. Further, M. haemasoma (L10: 9.3-18.5 mm) has 6-10 branchial filaments, ovoid postchaetal lobe, and ventral cirri with a swollen base until the last chaetiger.

Marphysa sherlockae n. sp. resembles M. angelensis Fauchald, 1970, M. brevitentaculata Treadwell, 1921, M. digitibranchia Hoagland, 1920, M. emiliae Molina-Acevedo \& Carrera-Parra, 2017, M. formosa Steiner \& Amaral, 2000, M. mangeri Augener, 1918, M. orensanzi CarreraParra \& Salazar-Vallejo, 1998 and M. sebastiana Steiner \& Amaral, 2000 by having compound falcigers and spinigers present; however, M. brevitentaculata, M. digitibranchia, and M. mangeri have limbate capillaries in the subacicular position from the middle to the posterior region of the body, while in $M$. sherlockae n. sp. these simple chaetae are absent. Furthermore, M. angelensis and $M$. emiliae have a digitiform postchaetal lobe in first four chaetigers, while in M. sherlockae n. sp. the postchaetal lobe is triangular at the same first chaetigers. Also, in M. emiliae (L10: 3.5$5.4 \mathrm{~mm}$ ) branchiae begin in chaetigers 8-12; while in M. sherlockae n. sp. (L10: 3-6.6 mm) branchiae begin from 25-34. On the other hand, M. formosa has pectinate branchiae, while $M$. sherlockae n. sp. have palmate branchiae with a short button-shaped branchial stem. Furthermore, M. formosa (TL: $55 \mathrm{~mm}$ ), M. orensanzi (TL: $12 \mathrm{~mm}$ ), and M. sebastiana (LT: $120 \mathrm{~mm}$ ) have up to 4-6 branchial filaments while $M$. sherlockae $\mathbf{n}$. sp. (TL: $67 \mathrm{~mm}$ ) only has two filaments. Finally, $M$. sebastiana and $M$. angelensis have short branchial filaments, while the filaments in $M$. sherlockae n. sp. are long.

\section{Discussion}

This study revealed that $M$. macintoshi and $M$. depressa recorded for the region actually represent (1) an incorrectly synonymized species, i.e., M. durbanensis that was reinstated herein, and (2) a new indigenous species that was previously overlooked and herein described, i.e., $M$. sherlockae n. sp., respectively. We also confirm the notion addressed by Lewis \& Karageorgopoulos (2008), that M. sanguinea is not present along the South African coast. However, the local species should be named M. haemasoma Quatrefages, 1866 and not M. elityeni Lewis \& Karageorgopoulos, 2008, since the latter is a junior synonym of the former.

Marphysa depressa and M. macintoshi were first recorded along the South African coast by Day $(1953,1967)$ with summary descriptions and general illustrations. The recurrent identification of M. macintoshi and M. depressa along the South African coast (e.g., Branch et al. 2016) reflects the overlooking of detailed characteristics and the use of traditional and conspicuous diagnostic features considered enough to define Marphysa species, such as the color and shape of the subacicular hook, distribution of compound chaetae throughout the body, the shape and distribution of branchiae, and the number of branchial filaments (Quatrefages 1866, Grube 1878, McIntosh 1910, Hartman 1944, Fauchald 1970, among others). The sole use of distinctive conspicuous features in the identification may lead to spurious records of cosmopolitanism in 
731 species (Hutchings \& Kupriyanova 2018), and also to the proliferation of misleading species 732 records and synonymization.

733

734

735

736

737

738

739

740

741

742

743

744

745

746

747

748

749

750

751

752

753

754

755

756

757

758

759

760

761

762

763

764

765

766

767

768

769

770

771

772

773

774

775

The detailed study of the traditional conspicuous features, the discovery of new unique characters as well as the examination of type specimens, as carried out here, has improved the morphological delimitation of Marphysa species, and the understanding of the diversity within the genus (e.g., Glasby \& Hutchings 2010; Molina-Acevedo \& Carrera-Parra 2015, 2017). Therefore, recent studies on Marphysa have focused on detecting unique characters or in the re-assessment of those forgotten features, such as the shapes of dorsal cirri, postchaetal lobes, and pectinate chaetae, and the first appearance of the ventral cirrus with a swollen base. For instance, Miura (1986) and Molina-Acevedo \& Carrera-Parra (2015) have shown that the distribution of the number of filaments and the region where the maximum number is reached can be informative in species delimitation. Here, the distribution of branchial filaments is different in each analyzed species (Fig. 4). Thus, whenever possible, it should be incorporated in future descriptions of Marphysa species. The main challenge of using "new" features in taxonomic investigations is the lack of this information in older descriptions preventing comparison. Thus, the examination of type material deposited in museums or examining newly collected material from the type locality in cases where no types were deposited previously is an essential step towards improving the taxonomy and recognition of new or inappropriate synonyms as in the case of M. haemasoma.

Molecular data provide an additional source of information that improves our knowledge on species boundaries and aids in recognition of intraspecific variation (e.g., Lewis \& Karageorgopoulos 2008; Zanol et al. 2016, 2017, Lavesque et al. 2017, Elgetany et al. 2018, Lavesque et al. 2019, Glasby et al. 2019, Abe et al. 2019, Martin et al. 2020). The phylogenetic tree revealed two distinct South African monophyletic clades, belonging to the new species $M$. sherlockae n. sp., and the other to M. haemasoma. The molecular analyses reinforced the reestablishment of M. haemasoma as a valid species by confirming its distinction from M. sanguinea, which concurs with previous findings from the region (Lewis \& Karageorgopoulos 2008). Furthermore, for the first time, this study provided COI sequences of M. haemasoma, from South Africa.

A total of nine Marphysa species have been newly proposed or redescribed under an integrative taxonomic framework since 2003 (Zanol et al. 2016; Zanol et al. 2017; Lavesque et al. 2017; Elgetany et al. 2018; Lavesque et al. 2019; Glasby et al. 2019; Abe et al. 2019; Martin et al. 2020; present study), thus, increasing the number of publicly available sequences of Marphysa species globally. This framework, in turn, provides a starting point from which other studies can address more complex hypotheses, such as resolving the phylogenetic placements of species within the genus.

This study has confirmed that the indigenous diversity of Marphysa in South Africa was indeed previously underestimated and thus increases the number of described indigenous species from three to five (Day 1967; Lewis \& Karageorgopoulos 2008) and reduces the number of putative cosmopolitan species to one (i.e., Marphysa corallina). Similarly, studies by Lewis \& Karageorgopoulos (2008); Clarke et al. (2010); Kara et al. (2018) and Simon et al. (2019) provide additional evidence that many cosmopolitan species reported in the Day (1967) polychaete monograph for this region are actually incorrect assignments. Undoubtedly, the polychaete monograph by Day (1967) is an invaluable resource for polychaete descriptions and distributions. However, it is widely used by researchers from many disciplines, including those working outside of the region (Hutchings \& Kupriyanova 2018). Thus, biologists locally and internationally should 
776

777

778

779

780

781

782

783

784

785

786

787

788

789

790

791

792

793

794

795

796

797

798

799

800

801

802

803

804

805

806

807

808

809

810

811

812

813

814

815

816

817

818

819

820

821 take cognizance of this fact and use the monograph with caution, especially concerning species considered "cosmopolitan".

Using information from Day (1967), Awad et al. (2002) determined that only 20\% of polychaete species in South Africa are endemic to the region. Thus, if only half the remaining $80 \%$ prove to be misidentifications of indigenous species, our understanding of diversity, biogeography, and endemism of polychaete worms in South Africa has been severely underestimated, and priority conservation areas may need to be reviewed. Furthermore, the resolution of taxonomically confusing species, such as those belonging to Marphysa, and development of realistic diversity estimates will be improved if voucher specimens are deposited in museums for taxonomic and molecular investigations.

\section{Conclusion}

Marphysa in South Africa is represented by six species, namely, M. capensis, M. corallina, M. durbanensis, M. haemasoma, M. posteriobranchia, and M. sherlockae n. sp. Although the number of species is similar to previous identifications, the resurrection of M. haemasoma, synonymization of $M$. elityeni with $M$. haemasoma, reinstatement of $M$. durbanensis from $M$. macintoshi and redescription of $M$. sherlockae $\mathbf{n}$. sp. from $M$. depressa has changed the composition of endemic and cosmopolitan species. As such, gaining a better understanding of our true local biodiversity may help us to understand the extent of biodiversity loss in the face of climate change and make better decisions regarding the designation of marine protected areas.

\section{Acknowledgments}

We sincerely thank Emma Sherlock (BMNH), Tarik Meziane (MNHN), Helmut Sattmann (NHM), and Able Bosman (SAM) for making available some of the materials that made this study possible. To Dr. Luis F. Carrera-Parra and Dr. Sergio I. Salazar-Vallejo for their advice and conversations about the morphology of the Eunicidae family. To Biol. Humberto Bahena-Basave (ECOSUR, Mexico) for advice on digital photography and editing. We also thank editors and reviewers whose comments made a significant contribution to improving this final version. We also thank Alheit $\mathrm{du}$ Toit for the collection and sequencing of wonder worm specimens. During this research, JK was supported by a Postdoctoral fellowship from the National Research Foundation (Grant Number: 116654), and ICMA was supported by a scholarship from CONACyT (514117/298079).

\section{References}

Abe H, Tanaka M, Taru M, Abe S, Nishigaki A. 2019. Molecular evidence for the existence of five cryptic species within Japanese species of Marphysa (Annelida: Eunicidae) known as "Iwa-mushi". Plankton Benthos Res. 14(4):303-314.

Aiyar RG. 1931. An account of the development and breeding habits of a brackish water Polychaete worm of the genus Marphysa. J. Linn. Soc. 37:387-403.

Augener H. 1918. Polychaeta. Beitrage zur Kenntnis der Meeresfauna Westafrikas. 2(2):67-625. 
822 Aylagas E, Borja A, Irigoien X, Rodriguez-Ezpeleta N. 2016. Benchmarking DNA metabarcoding

823

824

825

826

827

828

829

830

831

832

833

834

835

836

837

838

839

840

841

842

843

844

845

846

847

848

849

850

851

852

853

854

855

856

857

858

859

860

861

862

863

864

865

866

for biodiversity-based monitoring and assessment. Front. Mar. Sci. 3:96.

Awad AA, Griffiths CL, Turpie JK. 2002. Distribution of South African marine benthic invertebrates applied to the selection of priority conservation areas. Divers Distrib. doi: 10.1046/j.1472-4642.2002.00132.x

Baird W. 1869. Remarks on several genera of annelids, belonging to the group Eunicea, with a notice of such species as are contained in the collection of the British Museum, and a description of some others hitherto undescribed. J. Linn. Soc. 10:341-361.

Bickford D, Lohman DJ, Sodhi NS, Ng PKL, Meier R, Winker K, Ingram KK, Das I. 2007. Cryptic species as a window on diversity and conservation. Trends Ecol. Evol. 22:148-155.

Berthold AA. 1827. Latreille's Natürliche Familien des Thierreichs: Aus dem Franzosischen, mit Anmerkungen und Zusätzen. Verlage Landes-Industrie-Comptoirs, Weimar. pp. 606.

Branch G, Charles L.G, King, D. 2016. Two oceans: a guide to the marine life of Southern Africa. Struik Nature. pp. 464.

Carrera-Parra LF, Salazar-Vallejo SI. 1998. A new genus and 12 new species of Eunicidae (Polychaeta) from the Caribbean Sea. J. mar. biol. Ass. U.K. 78:145-182.

Clarke DT, Paterson GLJ, Florence WK, Gibbons MJ. 2010. A new species of Magelona (Polychaeta: Magelonidae) from southern Namibia. African Nat. Hist. 6:77-82.

Cole VJ, Chick RC, Hutchings PA. 2018. A review of global fisheries for polychaete worms as a resource for recreational fishers: diversity, sustainability and research needs. Rev. Fish Biol. Fisheries. 28:543-565. https://doi.org/10.1007/s11160-018-9523-4.

Crossland C. 1903. On the marine fauna of Zanzibar and British East Africa, from collections made by Cyril Crossland in the years 1901 and 1902. Polychaeta. Part I. Proc. zool. Soc. Lond. 73(1):169-176.

Dales RP. 1962. The polychaete stomodeum and the inter-relationships of the families of Polychaeta. Proc zool Soc Lond. 139:389-428.

Day JH. 1934. On a collection of South African Polychaeta, with a catalogue of the species recorded from South Africa, Angola, Mossambique, and Madagascar. J. Linn. Soc. (Zool.). 39(263):15-82.

Day JH. 1953. The polychaete fauna of South Africa. Part 2. Errant species from Cape shores and estuaries. Ann. Natal Mus. 12(3):397-441.

Day JH. 1962. Polychaeta from several localities in the western Indian Ocean. Proc. zool. Soc. Lond. 139(4):627-656.

Peer] reviewing PDF | (2020:05:48929:2:0:NEW 7 Sep 2020) 
867 Day JH. 1967. A Monograph on the Polychaeta of Southern Africa. Part I. Errantia. Br. Mus. nat. 868 Hist. pp. 458.

869

870

871

872

873

874

875

876

877

878

879

880

881

882

883

884

885

886

887

888

889

890

891

892

893

894

895

896

897

898

899

900

901

902

903

904

905

906

907

908

909

910

911

912

Day JH. 1974. A guide to marine life on South African shores. Second edition. A.A Balkema. pp. 300.

Ehlers E. 1904. Neuseeländische Anneliden. Abhandlungen der Königlichen Gesellschaft der Wissenschaften zu Göttingen Mathematisch-Physikalische Klasse. Neue Folge. 3(1):1-80.

Elgetany AH, El-Ghobashy AE, Ghoneim AM, Struck TH. 2018. Description of a new species of the genus Marphysa (Eunicidae), Marphysa aegypti sp. n., based on molecular and morphological evidence. Invertebr. Biol. 15(1):71-84.

Fauchald K. 1970. Polychaetous annelids of the families Eunicidae, Lumbrineridae, Iphitimidae, Arabellidae, Lysaretidae and Dorvilleidae from Western Mexico. Allan Hancock Monogr. mar. Biol. 5:1-335.

Fauvel P. 1902. Annélides Polychètes de la Casamance rapportées par M. Aug. Chevalier. Bull. Soc. Linn. Normandie, Series 5. 5:59-105.

Folmer O, Black M, Hoeh W, Lutz R, Vrijenhoek R. 1994. DNA primers for amplification of mitochondrial cytochrome c oxidase subunit I from diverse metazoan invertebrates. Mol. Mar. Biol. Biotechnol. 3:294-299.

Glasby CJ, Hutchings PA. 2010. A new species of Marphysa Quatrefages, 1865 (Polychaeta: Eunicida: Eunicidae) from northern Australia and a review of similar taxa from the Indowest Pacific, including the genus Nauphanta Kinberg, 1865. Zootaxa. 2352:29-45.

Glasby CJ, Mandario MA, Burghardt I, Kupriyanova E, Gunton LM, Hutchings PA. 2019. A new species of the sanguinea-group Quatrefages, 1866 (Annelida: Eunicidae: Marphysa) from the Philippines. Zootaxa. 4674(2):264-82.

Grube E. 1870. Bemerkungen über anneliden des Pariser Museums. Arch. Naturgesch. Berlin. 36(1):281-352.

Grube A.E. 1878. Die Familie Eunicea. Jahres-Bericht der Schlesischen Jber. schles. Ges. vaterl. Cult. Breslau. 55:79-104.

Hall TA. 1999. BioEdit: a user-friendly biological sequence alignment editor and analysis program for Windows 95/98/NT. Nucleic. Acids Symp. Ser. 41:95-98.

Hartman O. 1944. Polychaetous Annelids. Part V. Eunicea. Allan Hancock Pacific Exped. 10(1):1-237.

Hoagland RA. 1919. Polychaetous annelids from Porto Rico, the Florida Keys and Bermuda. Bull. Am. Mus. nat. Hist. 41:517-591.

Peer] reviewing PDF | (2020:05:48929:2:0:NEW 7 Sep 2020) 
913

914

915

916

917

918

919

920

921

922

923

924

925

926

927

928

929

930

931

932

933

934

935

936

937

938

939

940

941

942

943

944

945

946

947

948

949

950

951

952

953

954

955

956

Hutchings P, Kupriyanova E. 2018. Cosmopolitan polychaetes - fact or fiction? Personal and historical perspectives. Invertebr. Syst. 32:1-9.

Hutchings PA, Karageorgopoulos P (2003) Designation of a neotype of Marphysa sanguinea (Montagu, 1813) and a description of a new species of Marphysa from eastern Australia. Hydrobiologia. 496:87-94.

Idris I, Hutchings P, Arshad A. 2014. Description of a new species of Marphysa Quatrefages, 1865 (Polychaeta: Eunicidae) from the west coast of Peninsular Malaysia and comparisons with species from Marphysa Group A from the Indo-West Pacific and Indian Ocean. Mem. Mus. Vic. 71:109-121.

International Commission on Zoological Nomenclature (ICZN), 1999. International code of zoological nomenclature (4 Edition). The International Trust for Zoological Nomenclature, London.

Izuka A. 1912. The errantiata Polychaeta of Japan. J Coll Sci Imp Univ Tokyo. 30:1-262.

Kara J, Macdonald AHH, Simon CA. 2018. Integrative taxonomic methods reveal an incorrect synonymisations of the South African Pseudonereis podocirra (Schmarda) as the widespread Pseudonereis variegata (Grube) from Chile. Invertebr. Syst. 32:1282-1297.

Kinberg JGH. 1865. Annulata nova. Öfvers K VetenskAkad Förh Stockh. 21:559-574.

Knowlton N. 1993. Sibling Species in the Sea. Annu. Rev. Ecol. Syst. 24:189-216.

Kumar S, Stecher G, Li M, Knyaz C, Tamura K. 2018. MEGA X: Molecular Evolutionary Genetics Analysis across Computing Platforms. Mol. Biol. Evol. 35(6):1547-1549.

Lavesque N, Daffe G, Bonifacio P, Hutchings P. 2017. A new species of the Marphysa sanguinea complex from French waters (Bay of Biscay, NE Atlantic) (Annelida, Eunicidae). ZooKeys. 716:1-7.

Lavesque N, Daffe G, Grall J, Zanol J, Gouillieux B, Hutchings P. 2019. Guess who? On the importance of using appropriate name: case study of Marphysa sanguinea (Montagu, 1813). ZooKeys. 859:1-5.

Leray M, Knowlton N. 2015. DNA barcoding and metabarcoding of standardized samples reveal patterns of marine benthic diversity. Proc. Natl. Acad. Sci. U.S.A. 112(7):2076-81.

Lewis C, Karageorgopoulos P. 2008. A new species of Marphysa (Eunicidae) from the western Cape of South Africa. J. mar. biol. Ass. U.K. 88:277-287.

Peer] reviewing PDF | (2020:05:48929:2:0:NEW 7 Sep 2020) 
957

958

959

960

961

962

963

964

965

966

967

968

969

970

971

972

973

974

975

976

977

978

979

980

981

982

983

984

985

986

987

988

989

990

991

992

993

994

995

996

997

998

999

1000

1001

1002

Li S, Chen Y, Zhang M, Bao X, Li Y, Teng W, et al. 2016. Complete mitochondrial genome of the marine polychaete, Marphysa sanguinea (Polychaeta, Eunicida). Mitochondrial DNA Part A. 27(1):42-3.

Librado P, Rozas J. 2009. DnaSP v5: A software for comprehensive analysis of DNA polymorphism data. Bioinformatics. 25:1451-1452.

Liu Y, Hutchings PA, Sun S. 2017. Three new species of Marphysa Quatrefages, 1865 (Polychaeta: Eunicida: Eunicidae) from the south coast of China and redescription of Marphysa sinensis Monro, 1934. Zootaxa. 4263:228-250.

Liu Y, Hutchings PA, Kupriyanova E. 2018. Two new species of Marphysa Quatrefages, 1865 (Polychaeta: Eunicida: Eunicidae) from northern coast of China and redescription for Marphysa orientalis Treadwell, 1936. Zootaxa. 4377:191-215.

Lobo J, Teixeira MAL, Borges LMS, Ferreira MSG, Hollatz C, Gomes PT, et al. 2016. Starting a DNA barcode reference library for shallow water polychaetes from the southern European Atlantic coast. Mol. Ecol. Resour. 16(1):298-313.

Marenzeller E, von. 1888. Polychäten der Angra Pequena-Bucht. Zool. Jb. Syst. 3(1):1-24.

Martin D, Gil J, Zanol J, Meca MA, Perez-Portela R. 2020. Digging the diversity of Iberian bait worms Marphysa (Annelida, Eunicidae). PLoS ONE. 15(1):e0226749.

McIntosh, W.C. 1910. A monograph of the British annelids. Polychaeta. Syllidae to Ariciidae. Ray Society of London. 2(2):233-524.

Miura, T. 1986. Japanese polychaetes of the genera Eunice and Euniphysa: Taxonomy and branchial distribution patterns. Publs Seto mar. biol. Lab. 31(3):269-325.

Molina-Acevedo IC. 2018. Morphological revision of the Subgroup 1 Fauchald, 1970 of Marphysa de Quatrefages, 1865 (Eunicidae: Polychaeta). Zootaxa. 4480(1):001-125.

Molina-Acevedo IC, Carrera-Parra LF. 2015. Reinstatement of three Grand Caribbean species of the Marphysa sanguinea complex (Polychaeta: Eunicidae). Zootaxa. 3925:37-55.

Molina-Acevedo IC, Carrera-Parra LF. 2017. Revision of Marphysa de Quatrefages, 1865 and some species of Nicidion Kinberg, 1865 with the erection of a new genus (Polychaeta: Eunicidae) from the Grand Caribbean. Zootaxa. 4241:001-062.

Molina-Acevedo IC, Idris I. 2020. Reinstatement of species belonging "Marphysa sanguinea complex" (Annelida: Eunicidae) and description of new species from the mid-Pacific Ocean and the Adriatic Sea. Zootaxa. 4816(1):001-048.

Montagu G. 1813. Descriptions of several new or rare animals principally marine, found on the south coast of Devonshire. Linn. Soc. London Trans. 11:18-21.

Peer) reviewing PDF | (2020:05:48929:2:0:NEW 7 Sep 2020) 
1003

1004

1005

1006

1007

1008

1009

1010

1011

1012

1013

1014

1015

1016

1017

1018

1019

1020

1021

1022

1023

1024

1025

1026

1027

1028

1029

1030

1031

1032

1033

1034

1035

1036

1037

1038

1039

1040

1041

1042

1043

1044

1045

1046
Nygren A. 2014. Cryptic polychaete diversity: A review. Zool. Scr. 43:172-183.

Nylander JAA. 2004. MrModelTest v2. Program distributed by the author. Evolutionary Biology Centre, Uppsala University.

Parapar J, Besteiro C, Urgorri V. 1993. Taxonomy and Ecology of Annelida of the Iberian Peninsula - Polychaeta from the Ria-De-Ferrol. Cah. Biol. Mar. 34:411-432.

Pillai TG. 1958. Studies on a brackish-water polychaetous annelid, Marphysa borradailei sp. $\mathrm{n}$. from Ceylon. Ceylon J. Sci. biol. Sci. 1(2):94-106.

Quatrefages A. de. 1865a. Note sur la classification des Annélides. Cr hebd Séanc Acad Sci. 60:586-600.

Quatrefages A. de. 1865b. Note sur la Classification des Annelides. Annls. Sci. Nat. Paris. 3:253296.

Quatrefages A. de. 1866 [1865]. Histoire Naturelle des Annelés Marins et d’Eau Douce: Annélides et Géphyriens. Tome Premier. Collection des Suites a Buffon formant avec les Oeuvres de cet auteur un Cours Complet d'Histoire Naturelle. Librairie Encyclopédique de Roret, Paris, 588 pp. [Wright, E.P. (1866) Annelida. Zoological Record, Section 6 (Annelida, etc.), pp.578-600].

Rambaut A, Drummond AJ. 2013. Tracer v1.6. Available from http//tree.bio.ed.ac.uk/software/tracer.

Read G, Fauchald K. (Ed.). 2018. World Polychaeta database. Marphysa macintoshi Crossland, 1903.

Accessed

at: http://www.marinespecies.org/polychaeta/aphia.php?p=taxdetails\&id=209833 on 202003-26.

Ronquist F, Teslenko M, Van Der Mark P, Ayres DL, Darling A, Höhna S, Larget B, Liu L, Suchard MA, Huelsenbeck JP. 2012. Mrbayes 3.2: Efficient bayesian phylogenetic inference and model choice across a large model space. Syst. Biol. 61:539-542.

Salazar-Vallejo SI, Carrera-Parra LF. 1998. Eunícidos (Polychaeta) del Caribe mexicano con claves para las especies del Gran Caribe: Fauchaldius, Lysidice, Marphysa, Nematonereis y Palola. Rev. Biol. Trop. 45:1481-1498.

Schmarda LK. 1861. Neue wirbellose Thiere beobachtet und gesammelt auf einer Reise un die Erdr 1853 bis 1857. Erster Band (zweite halfte) Turbellarian, Rotatorien un Anneliden. 2:1-164. 
1047 Simon CA, Sato-Okoshi W, Abe H. 2019. Hidden diversity within the cosmopolitan species

1048

1049

1050

1051

1052

1053

1054

1055

1056

1057

1058

1059

1060

1061

1062

1063

1064

1065

1066

1067

1068

1069

1070

1071

1072

1073

1074

1075

1076

1077

1078

1079

1080

1081

1082

1083

1084

1085

1086

1087

1088

1089

1090

1091

Pseudopolydora antennata (Claparède, 1869) (Spionidae: Annelida). Mar. Biodivers. 49:25-42.

Southern R. 1921. Polychaeta of the Chilka Lake and also of fresh and brackish waters in other parts of India. Indian Mus. Calcutta Mem. 5:563-659.

Steiner TM, Amaral ACZ. 2000. Two new species of Marphysa Quatrefages, 1865 (Eunicidae, Polychaeta) from intertidal sandy beaches of the Sao Sebastiao Channel, State of Sao Paulo (Brazil). Bull. mar. Sci. 67(1):479-490.

Swofford DL. 2003. PAUP*. Phylogenetic Analysis Using Parsimony (*and other methods). Cersion 4. Sinauer Associates, Sunderland, Massachusetts.

Thompson J.D, Higgins D.G, Gibson T.J. 1994. CLUSTAL W: improving the sensitivity of progressive multiple sequence alignment through sequence weighting, position-specific gap penalties and weight matric choice. Nucleic Acids Res. Spec. Publ. 22(22):4673-4680.

Treadwell, A.L. (1906) Polychaetous annelids of the Hawaiian Islands collected by the steamer Albatross in 1902. Bull. U.S. Fish. Comm. 23(3):1145-1181.

Treadwell AL. 1917. Polychaetous annelids from Florida, Porto Rico, Bermuda and the Bahamas. Carnegie Inst. Wash. Publ. 251:255-272.

Treadwell AL. 1921. Leodicidae of the West Indian region. Carnegie Inst. Wash. Publ. 15(293):1131.

Watson GJ, Murray JM, Schaefer M, Bonner A. 2017. Bait worms: a valuable and important fishery with implications for fisheries and conservation management. Fish Fish. 18:374388.

Wang Z, Zhang Y, Qiu JW. 2018. A New Species in the Marphysa sanguinea Complex (Annelida, Eunicidae) from Hong Kong. Zool. Stud. 57(48):1-13.

Webster HE. 1884. Annelida from Bermuda collected by G. Brown Goode. Bull. U.S. Nat. Mus. 25:307-32.

Willey A. 1904. Littoral Polychaeta from the Cape of Good Hope. Linn. Soc. London Trans. Series 2, Zoology. 9(6):255-268.

Zanol J, da Silva TSC, Hutchings P. 2016. Marphysa (Eunicidae, polychaete, Annelida) species of the Sanguinea group from Australia, with comments on pseudo-cryptic species. Invertebr. Biol. 135(4):328-344.

Zanol J, da Silva TSC, Hutchings P. 2017. One new species and two redescriptions of Marphysa (Eunicidae, Annelida) species of the Aenea-group from Australia. Zootaxa. 4268(3):411426.

Peer) reviewing PDF | (2020:05:48929:2:0:NEW 7 Sep 2020) 
1092

1093

1094

1095
Zhang J, Kapli P, Pavlidis P, Stamatakis A. 2013. A general species delimitations method with applications to phylogenetic placements. Bioinformatics. 29(22):2869-2876. 
Figure 1

Sampling localities of M. depressa (Langebaan, Strand), M. macintoshi (Durban Bay), M. haemasoma (Table Bay) and M. elityeni (Buffels Bay and Kommetjie) from South Africa.

Triangles represent museum material examined and circles represent samples collected in 2017 (M elityeni - Kommetjie) and 2019 (M. depressa - Strand).

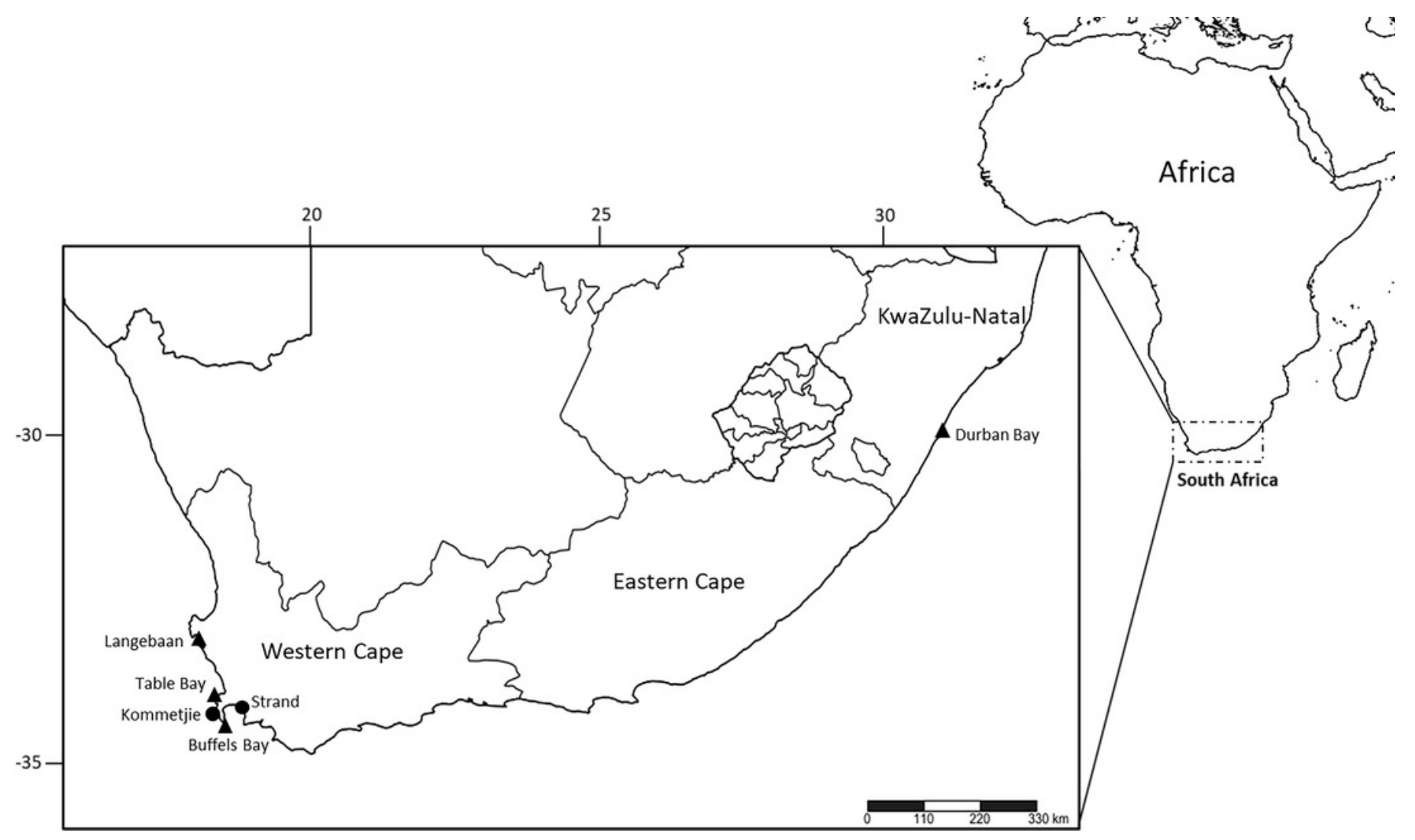




\section{Figure 2}

Phylogenetic tree based on the mitochondrial cytochrome c oxidase subunit 1 alignment of Marphysa spp.

Bayesian posterior probabilities and maximum likelihood bootstrap values $>95 \%$ are represented by an * at each node with the former on the left side of forward slash and latter on the right side of the forward slash. The hyphens, -, represent nodes that had maximum likelihood values $<90 \%$. Purple clade - the reinstated M. haemasoma. Blue clade - newly described M. sherlockae $\mathbf{n}$. sp. 


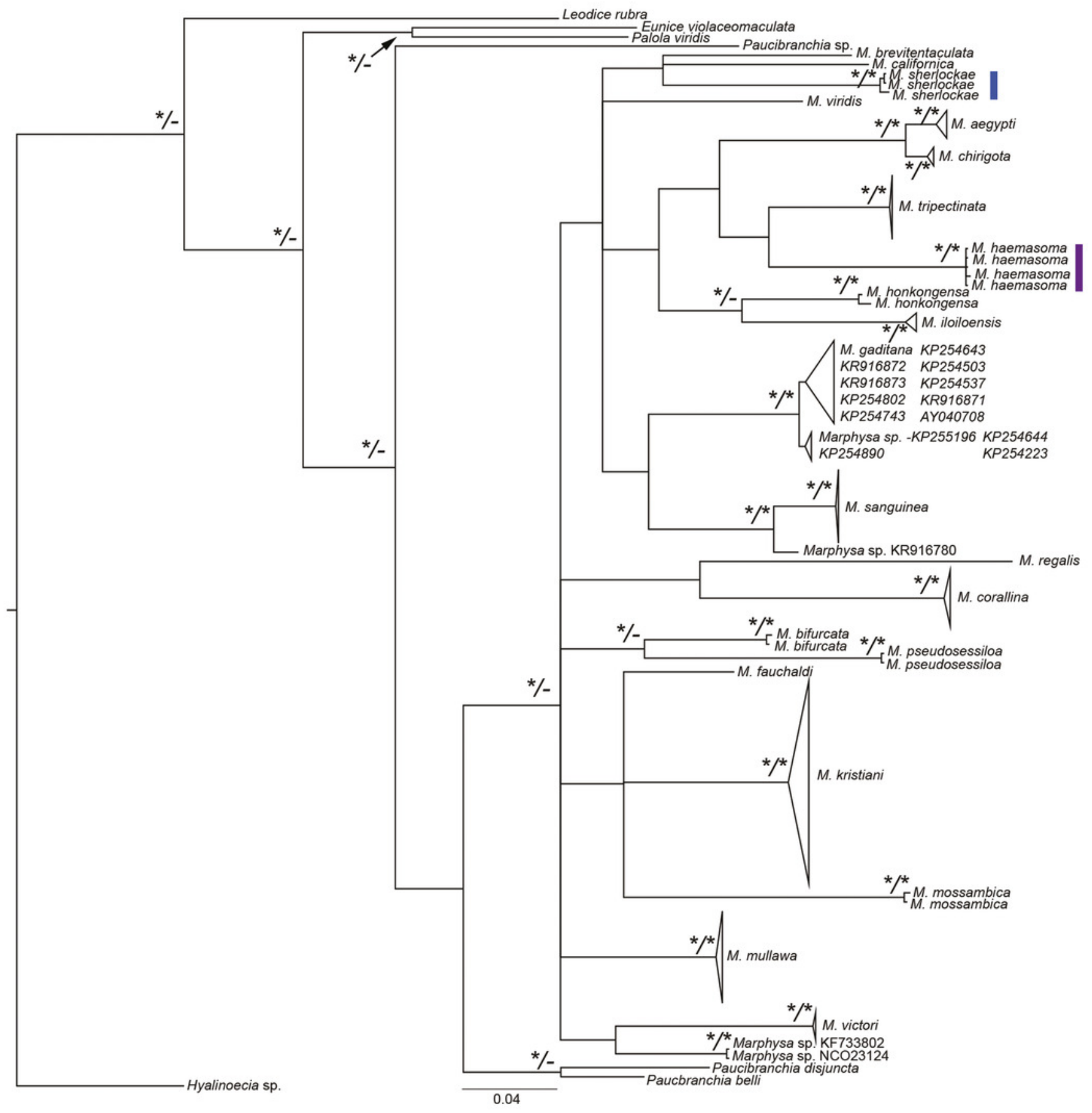




\section{Figure 3}

Marphysa durbanensis Day, 1934.

A. Anterior end, dorsal view; B. Anterior end, ventral view; C. Anterior view, lateral view; D. Maxillary apparatus, dorsal view; E. Left MI-II-III-IV-V, lateral view; F. Mandible; G. Parapodium 3; H. Parapodium 8; I. Parapodium 12; J. Parapodium 69; K. Parapodium 217; L. Thin narrow isodont pectinate with long and slender teeth, chaetiger 3; M. Thin wide isodont with short and slender teeth, chaetiger 69; N. Thick wide isodont pectinate with short and thick teeth, chaetiger 140; O. Thick wide anodont with short and slender teeth, chaetiger 140; P. Compound spinigers, chaetiger 3; Q. Subacicular hook, chaetiger 278. A-C, G-P from Lectotype BMNH 1934.1.19.166; D-F, Q from paralectotype BMNH 1934.1.19.166. All chaetigers in anterior view; LMI-II: Ligament between MI and MII; LMII-III: Ligament between MII and MIII. Scale bars: A-C, $3.5 \mathrm{~mm}$; D-E, $0.9 \mathrm{~mm} ; \mathrm{F}, 0.8 \mathrm{~mm} ; \mathrm{G}-\mathrm{K}, 0.2 \mathrm{~mm}$; L-O, Q $30 \mu \mathrm{m}$; $\mathrm{P}, 0.1 \mathrm{~mm}$. 


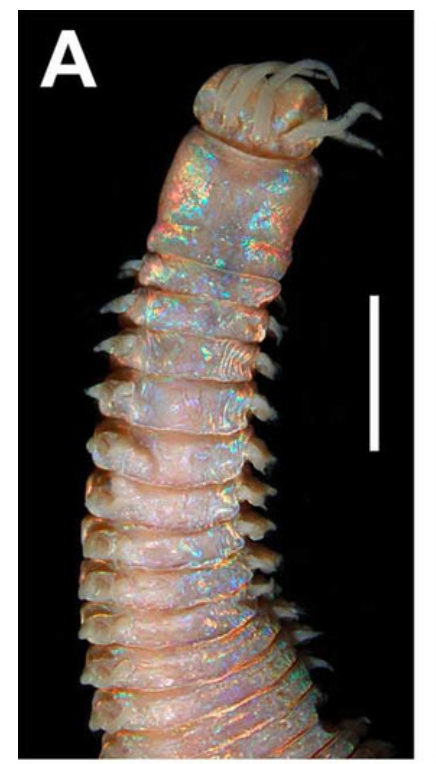

D
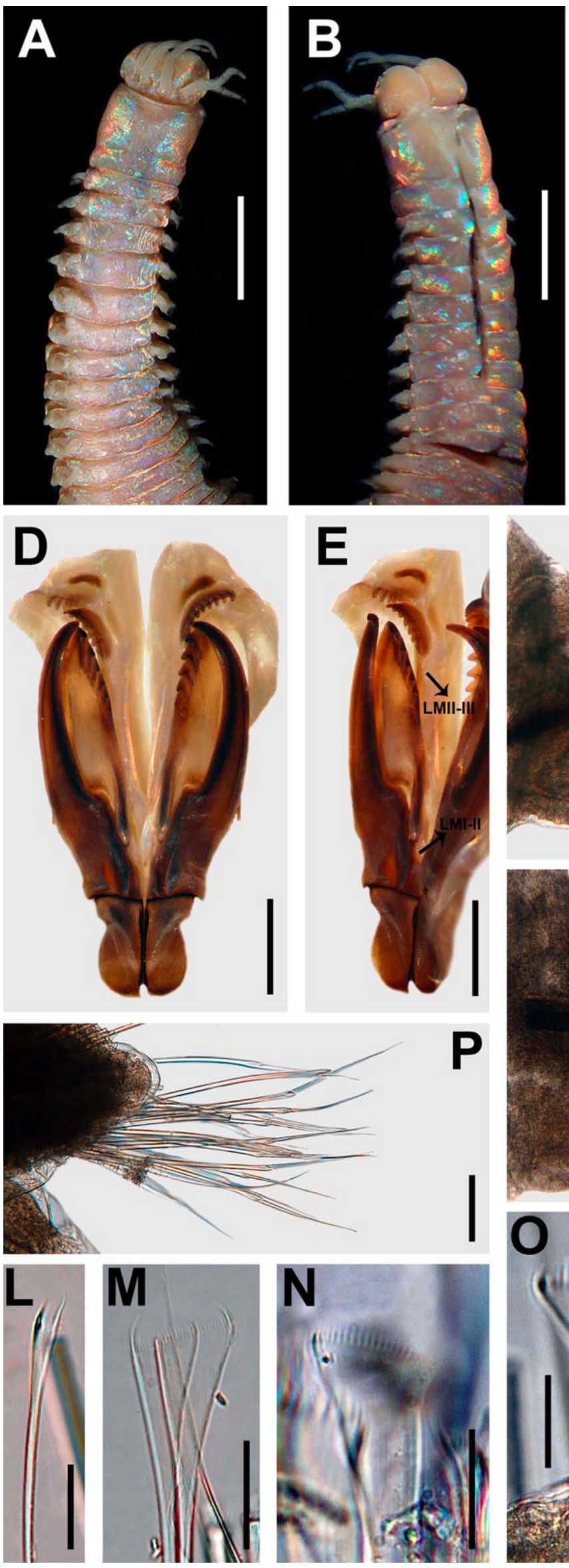

E

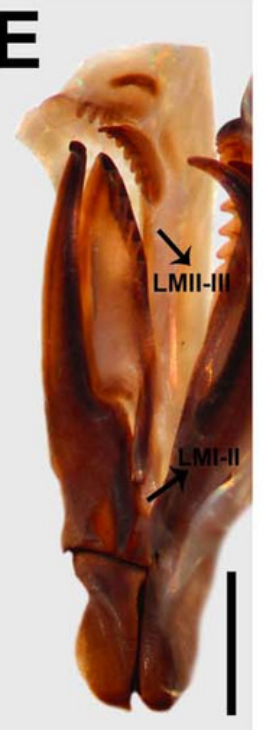

P
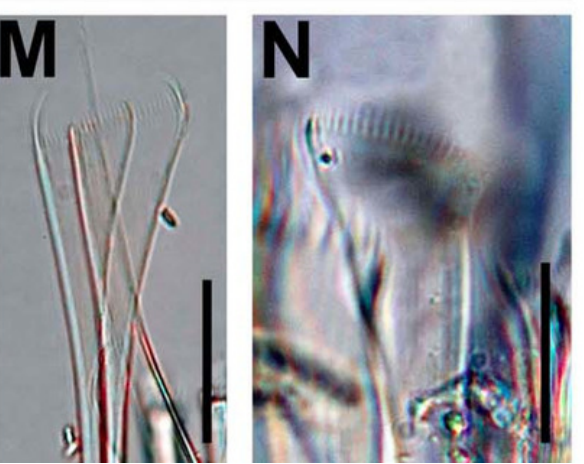

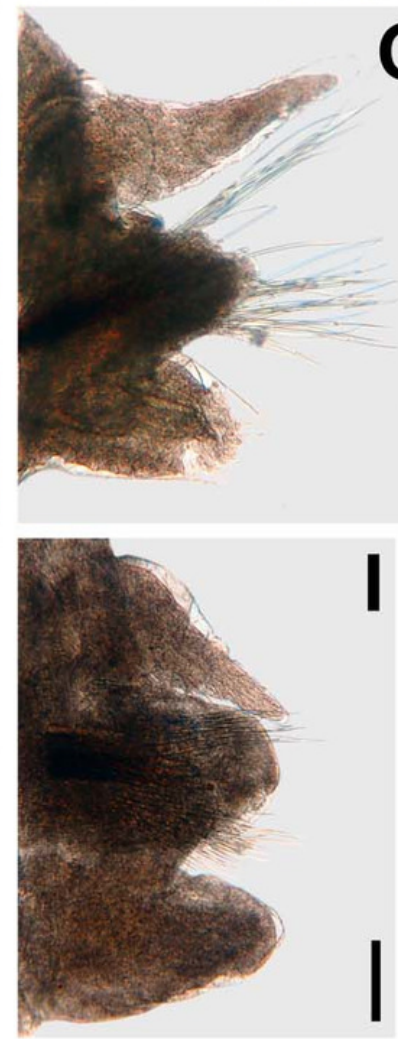

G
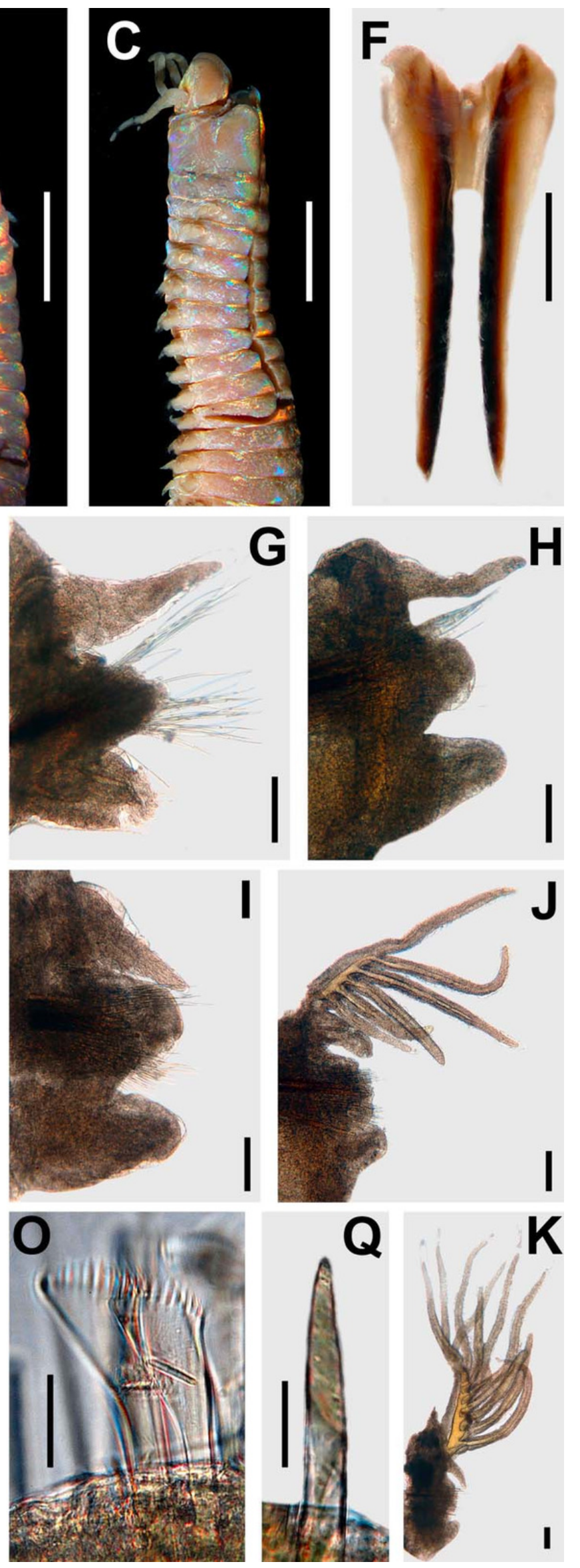

Peer] reviewing PDF | (2020:05:48929:2:0:NEW 7 Sep 2020) 
Figure 4

Distribution of branchial filaments throughout the body in

A. Marphysa durbanensis Day, 1934 (L10: 14 mm, 380 chaetigers); B. Marphysa haemasoma Quatrefages, 1865 (L10: 123 mm, 322 chaetigers); C. Marphysa sherlockae n. sp. (L10: 6.6 $\mathrm{mm}, 208$ chaetigers).

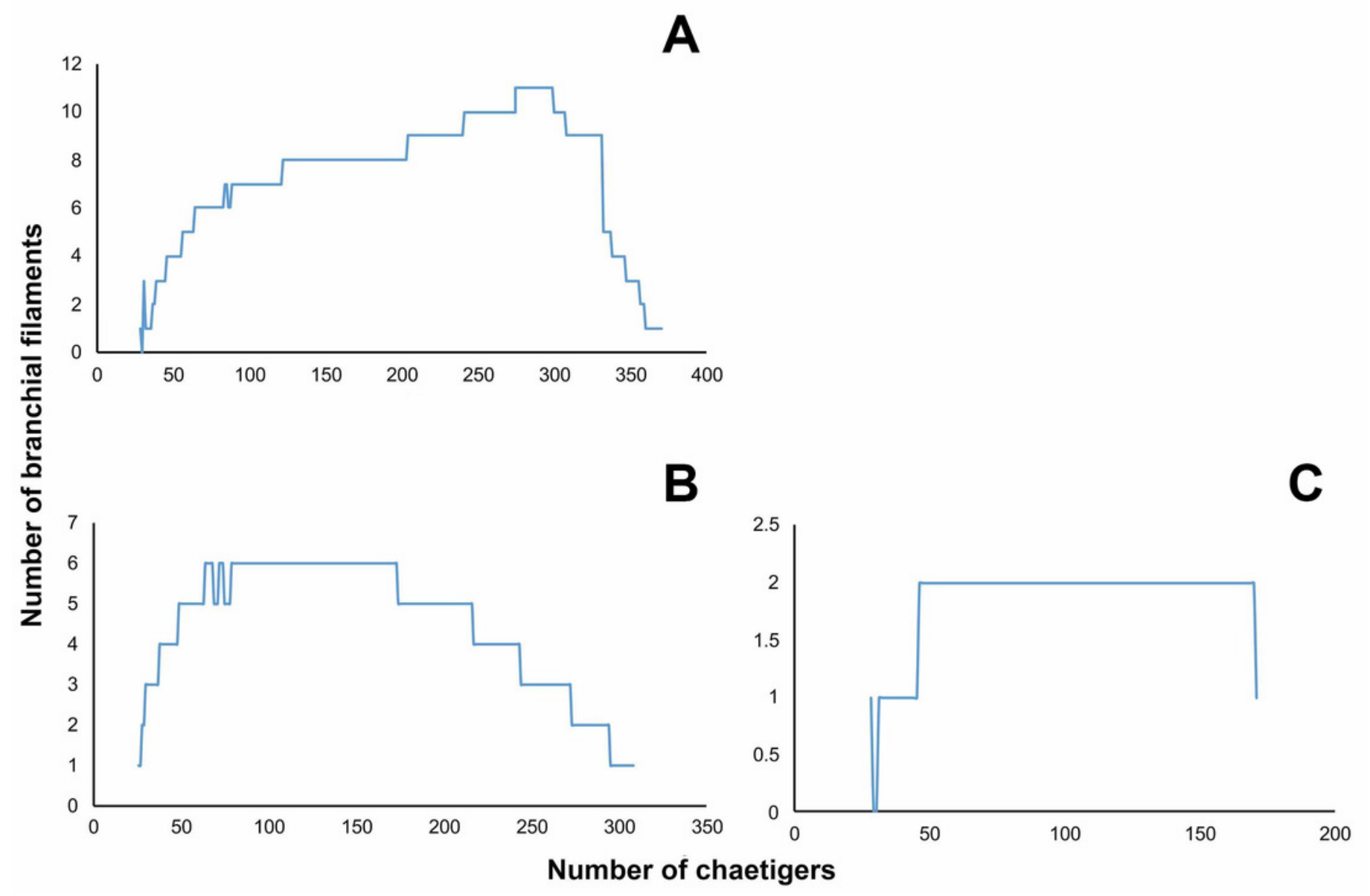


Figure 5

Marphysa durbanensis Day, 1934, lectotype BMNH 1934.1.19.166.

A. Thin narrow isodont pectinate with long and slender teeth, chaetiger 3; B. Thin wide isodont with short and slender teeth, chaetiger 69; C. Thick wide isodont pectinate with short and thick teeth, chaetiger 140; D. Thick wide anodont with short and slender teeth, chaetiger 140. Scale bars: A-D, $30 \mu \mathrm{m}$.

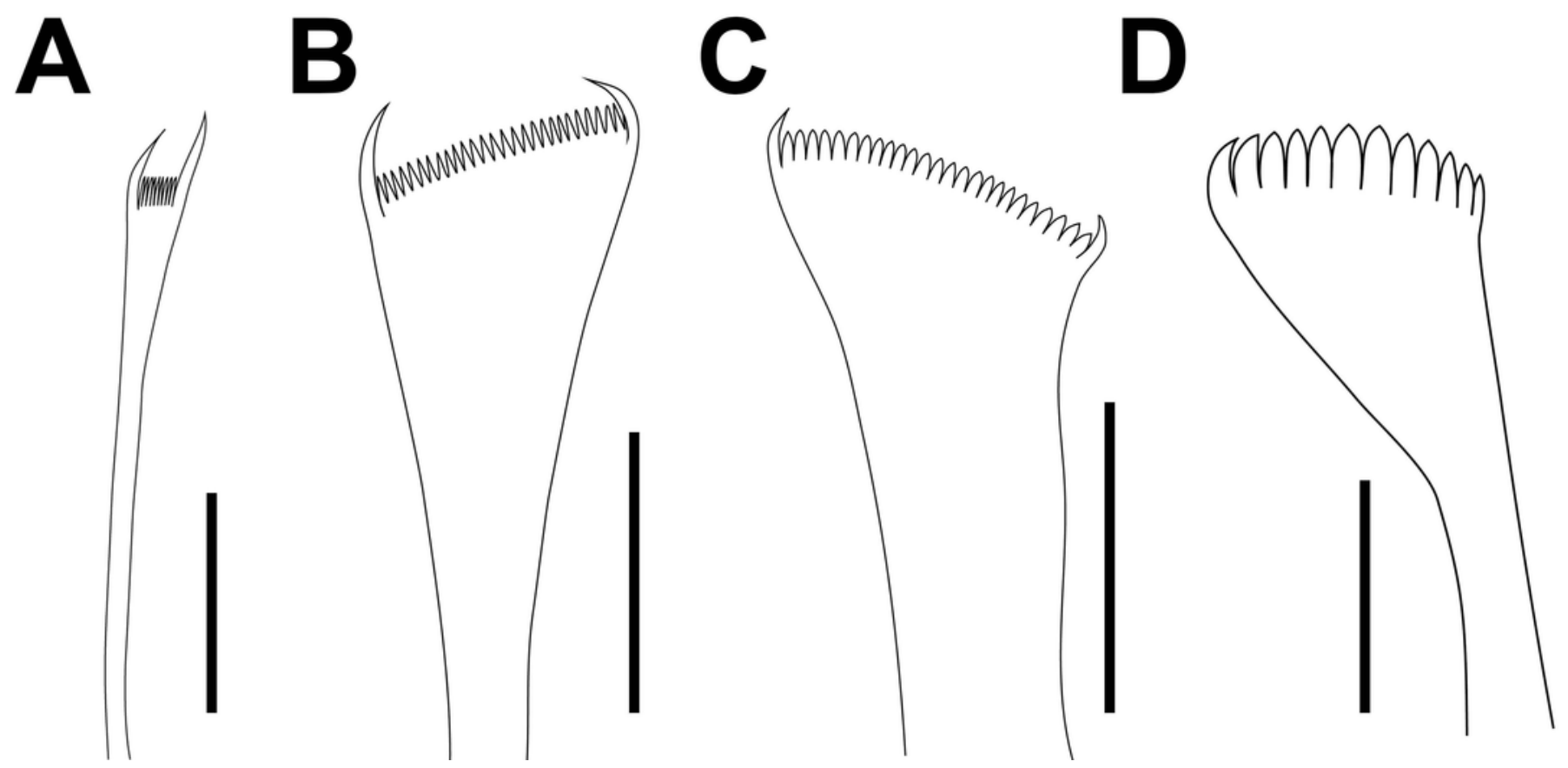




\section{Figure 6}

Marphysa haemasoma Quatrefages, 1866

A. Anterior end, dorsal view; B. Anterior end, ventral view; C. Anterior view, lateral view; D. Maxillary apparatus, dorsal view; E. Left MI-II-III-IV-V, lateral view; F. Mandible; G. Parapodium 3; H. Parapodium 12; I. Parapodium 30; J. Parapodium 154; K. Parapodium 307; L. Thin narrow isodont with long and slender teeth, chaetiger 3; $M$. Thick wide isodont with short and slender teeth, chaetiger 251; N. Thick wide anodont with short and slender teeth, chaetiger 307; O. Thick wide anodont with long and thick teeth, chaetiger 251; P. Compound spinigers, chaetiger 3; Q. Subacicular hook, chaetiger 209. A-B, D-E, G-L, N, P from Holotype $M$. haemasoma MNHN type 613; F, M, O, Q from Paratype Marphysa elityeni BMNH 2007.69. All chaetigers in anterior view; al-MIII: attachment lamella MIII; al-MIV: attachment lamella MIV; LMI-II: Ligament between MI and MII; LMII-III: Ligament between MII and MIII. Scale bars: A-B, $3.1 \mathrm{~mm}$; C, 3.8mm; D-E, $1.2 \mathrm{~mm}$; F, $1.7 \mathrm{~mm}$; G-K, $0.2 \mathrm{~mm}$; L-O, Q, $30 \mu \mathrm{m} ; \mathrm{P}, 0.1 \mathrm{~mm}$. 

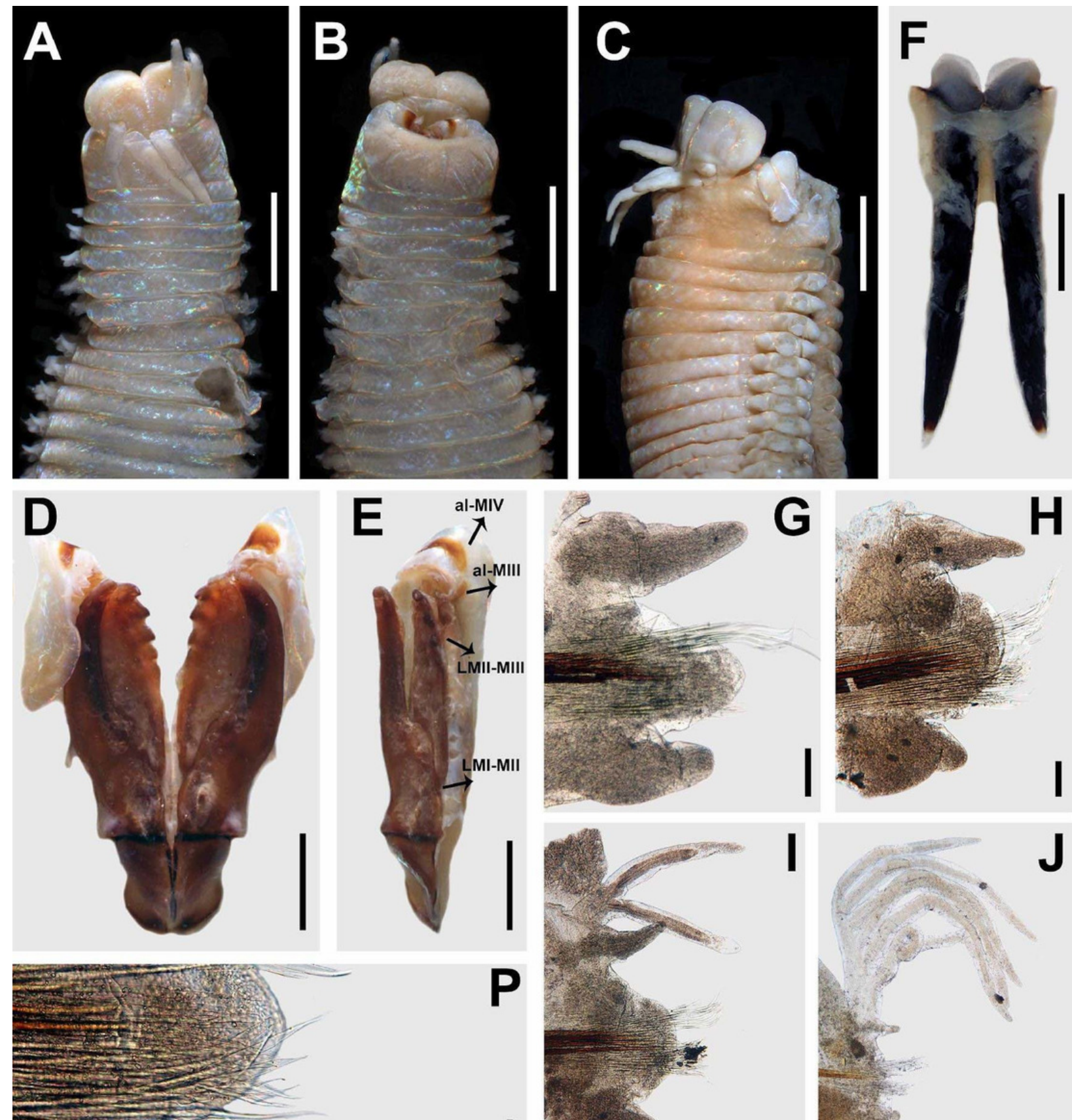

$H$
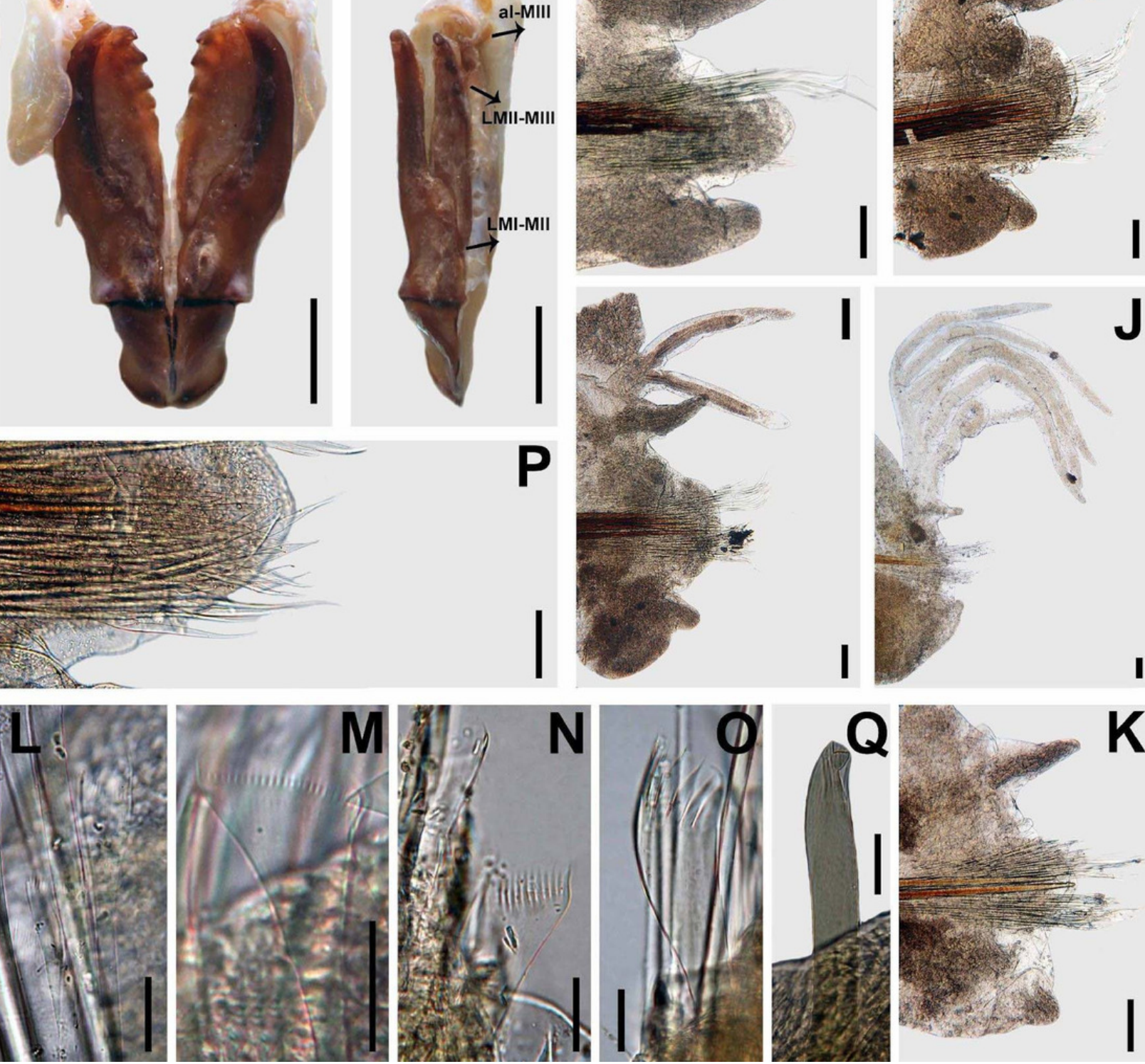


\section{Figure 7}

Marphysa haemasoma Quatrefages, 1866. Type and additional material from Marphysa elityeni Lewis \& Karageorgopoulos, 2008.

A. Anterior end, dorsal view; B. Left MI-II-III-IV-V, lateral view; C. Right MI-II-IV-V, lateral view;

D. Parapodium 3; E. Parapodium 13; F. Parapodium 208; G. Parapodium 3; H. Parapodium 12;

I. Thick wide anodont with short and slender teeth, chaetiger 209; J. Thick wide isodont with short and slender teeth, chaetiger 209; K. Subacicular hook, chaetiger 209. A-F, from paratype Marphysa elityeni BMNH 2007.69; G-H from holotype M. haemasoma MNHN type 613; I-K, from topotype Marphysa elityeni BMNH 237. Chaetigers D-E, G-H in posterior view, chaetiger $\mathrm{F}$ in anterior view; al-MIII: attachment lamella MIII; al-MIV: attachment lamella MIV; LMI-II: Ligament between MI and MII; LMII-III: Ligament between MII and MIII; LMII-IV: Ligament between MII and MIV; PL: Postchaetal lobe. Scale bars: A, $4.6 \mathrm{~mm}$; B-C, $1.8 \mathrm{~mm}$; D-E, $0.4 \mathrm{~mm}$; G-H, $0.2 \mathrm{~mm}$; I-J, $30 \mu \mathrm{m}$. 

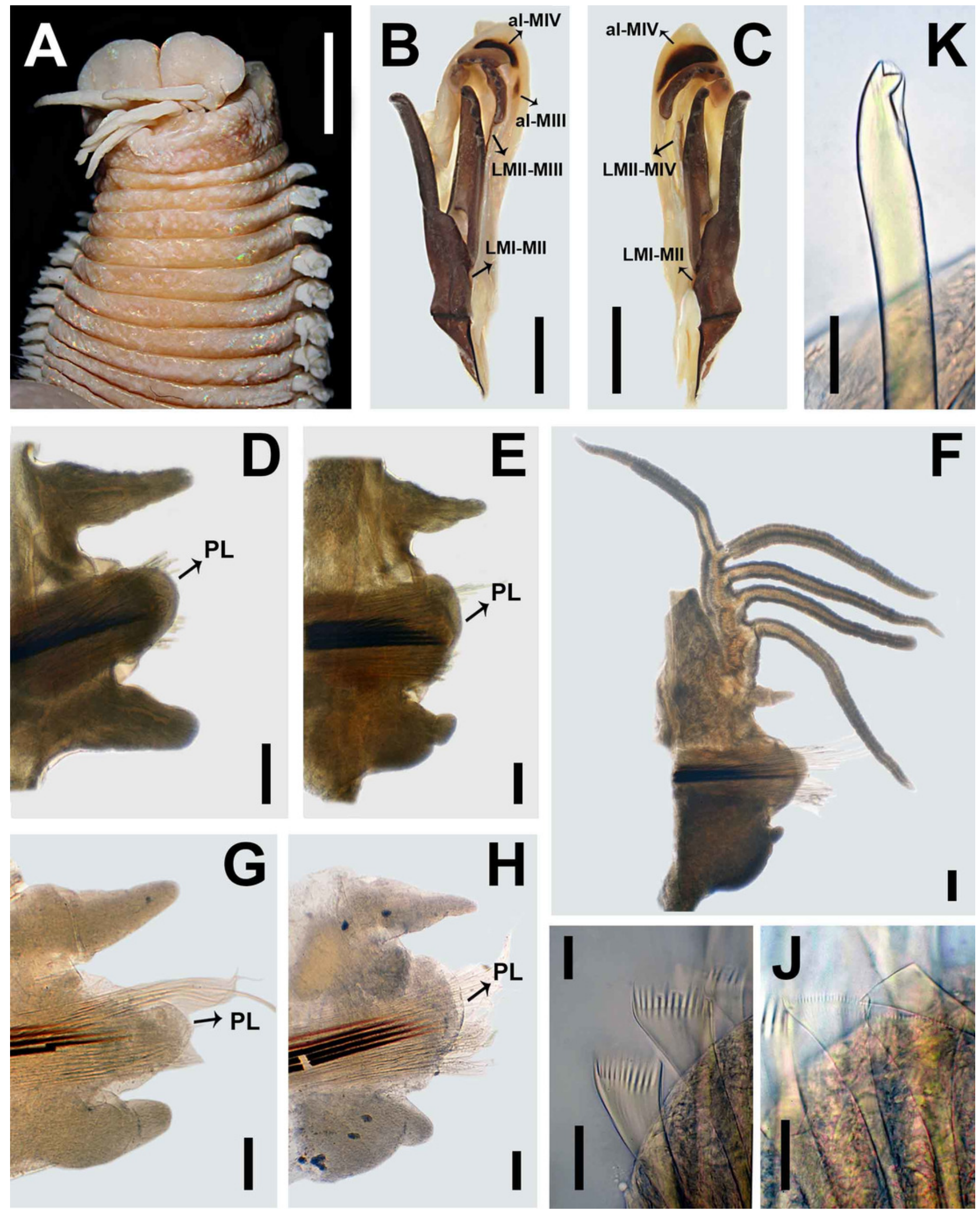


\section{Figure 8}

Marphysa sherlockae n. sp. Holotype BMNH 1963.1.84.

A. Anterior end, dorsal view; B. Anterior end, ventral view; C. Anterior end, ventral view; D. Maxillary apparatus, dorsal view; E. Left MI-II-III-IV-V, lateral view; F. Mandible; G. Parapodium 3; H. Parapodium 6; I. Parapodium 14; J. Parapodium 114; K. Parapodium 185 L. Thin narrow isodont with long and slender teeth, chaetiger 3; M. Thick wide isodont with long and thick teeth, chaetiger 185; N. Compound spinigers, chaetiger 3; O. Compound falcigers, chaetiger 3; P. Subacicular hook, chaetiger 49. All chaetigers in anterior view; al-MIII: attachment lamella MIII; al-MIV: attachment lamella MIV; LMI-II: Ligament between MI and MII; LMII-III: Ligament between MII and MIII. Scale bars: A-C, $1.7 \mathrm{~mm}$; D-E, $0.6 \mathrm{~mm} ; \mathrm{F}, 0.4 \mathrm{~mm}$; G-K, 0.1 $\mathrm{mm} ; \mathrm{N}-\mathrm{P}, 30 \mu \mathrm{m}$. 

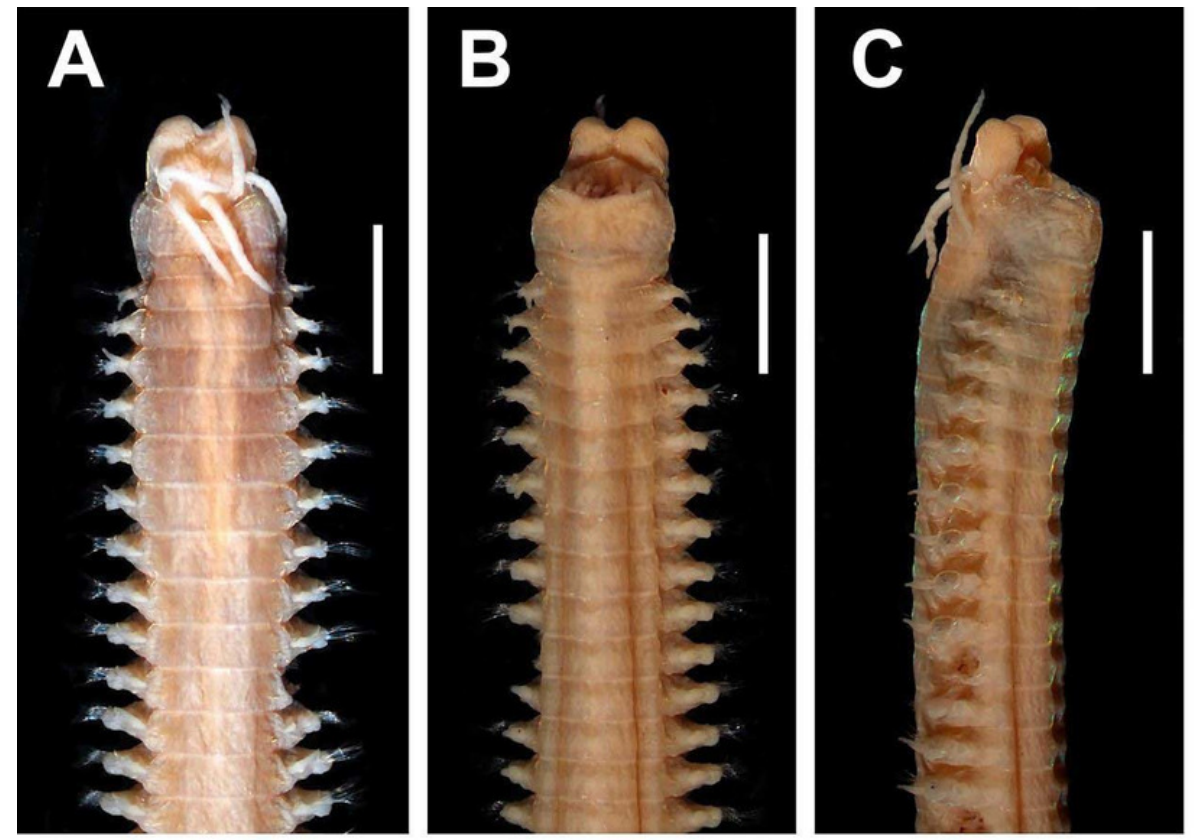

$\mathbf{F}$
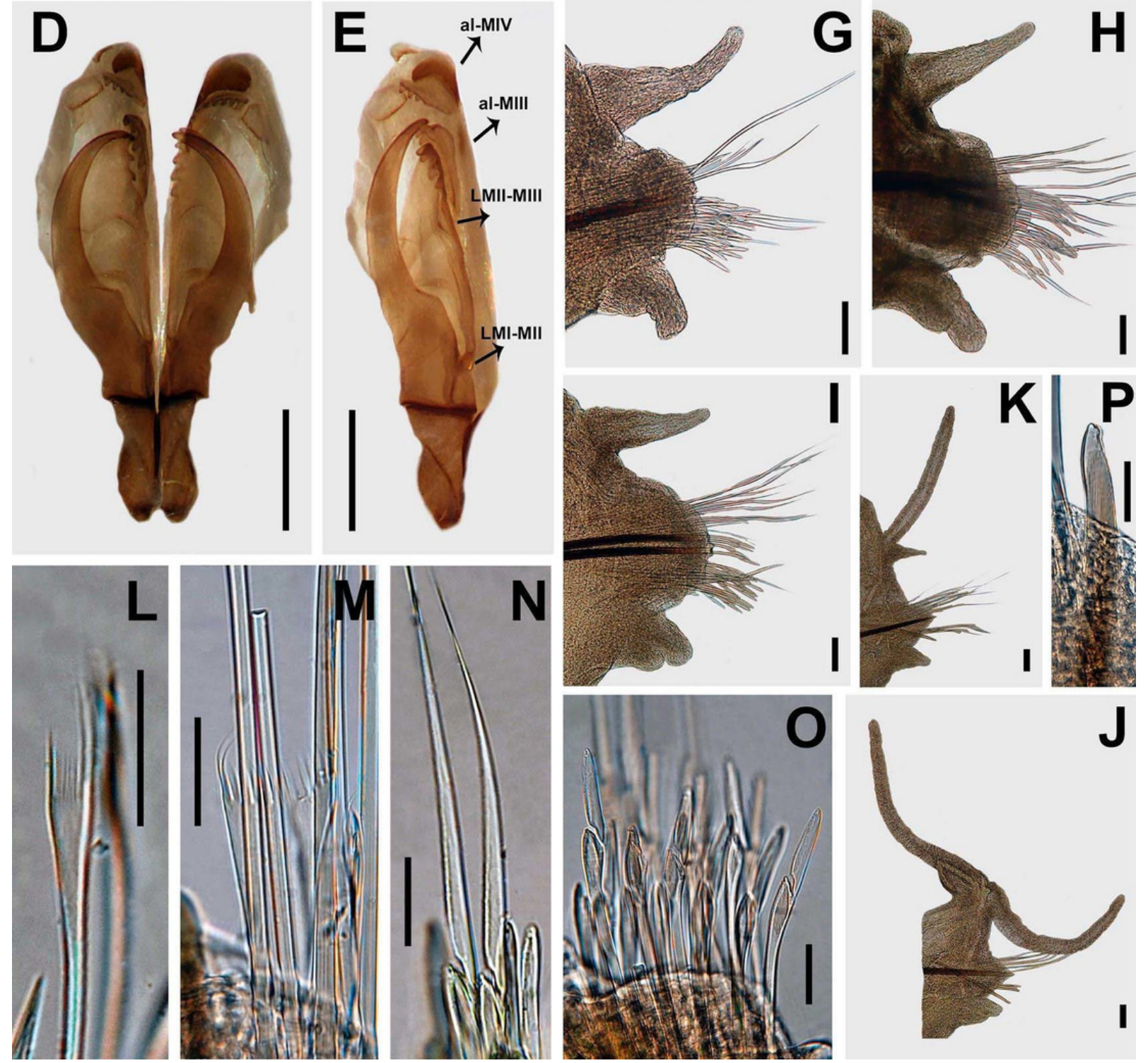


\section{Figure 9}

Marphysa sherlockae n. sp.

A. Thin narrow isodont pectinate chaetae with long and slender teeth, anterior chaetiger; B. Thin narrow isodont pectinate chaetae with long and slender teeth, anterior chaetiger; C. Thick narrow isodont pectinate chaetae with long and slender teeth, chaetiger 32; D. Thick wide isodont pectinate chaetae wide with long and thick teeth, posterior chaetiger; E. Thick wide isodont pectinate chaetae with long and thick teeth, posterior chaetiger. A, B, C from SAMC-A20578; D, E SAMC-A089089 Scale bars: A-E, $0.05 \mathrm{~mm}$. 

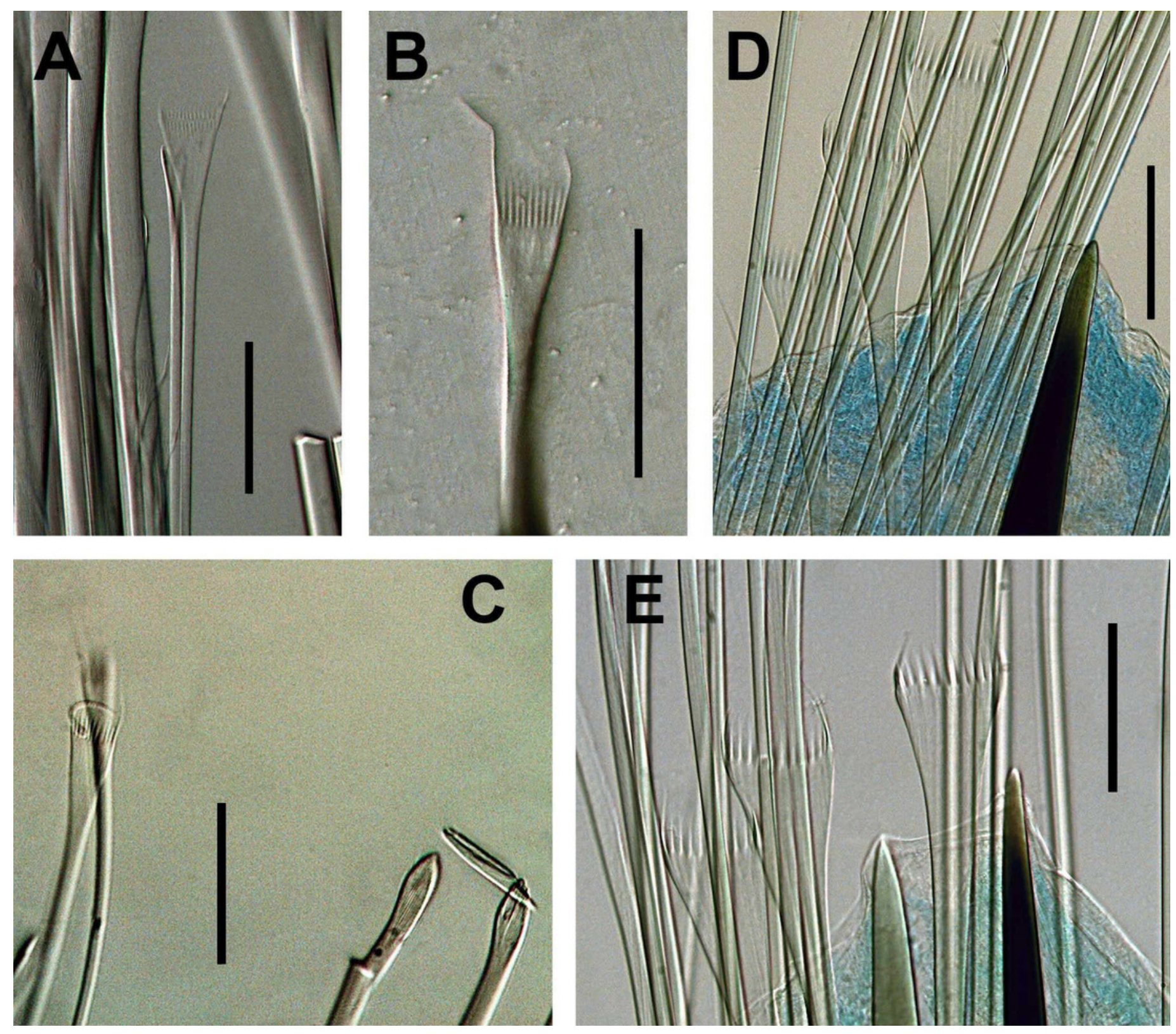
Figure 10

Length-dependent variation of some morphological features in Marphyssa sherlockae $\mathrm{n}$. sp.

Orange point: Chaetiger where subacicular hook start $(p=0.35, n=11)$. Blue points: First chaetiger with branchia ( $p=0.26, n=11)$; Green points: Maximum number of branchial filaments $(p=0.00, n=11)$.

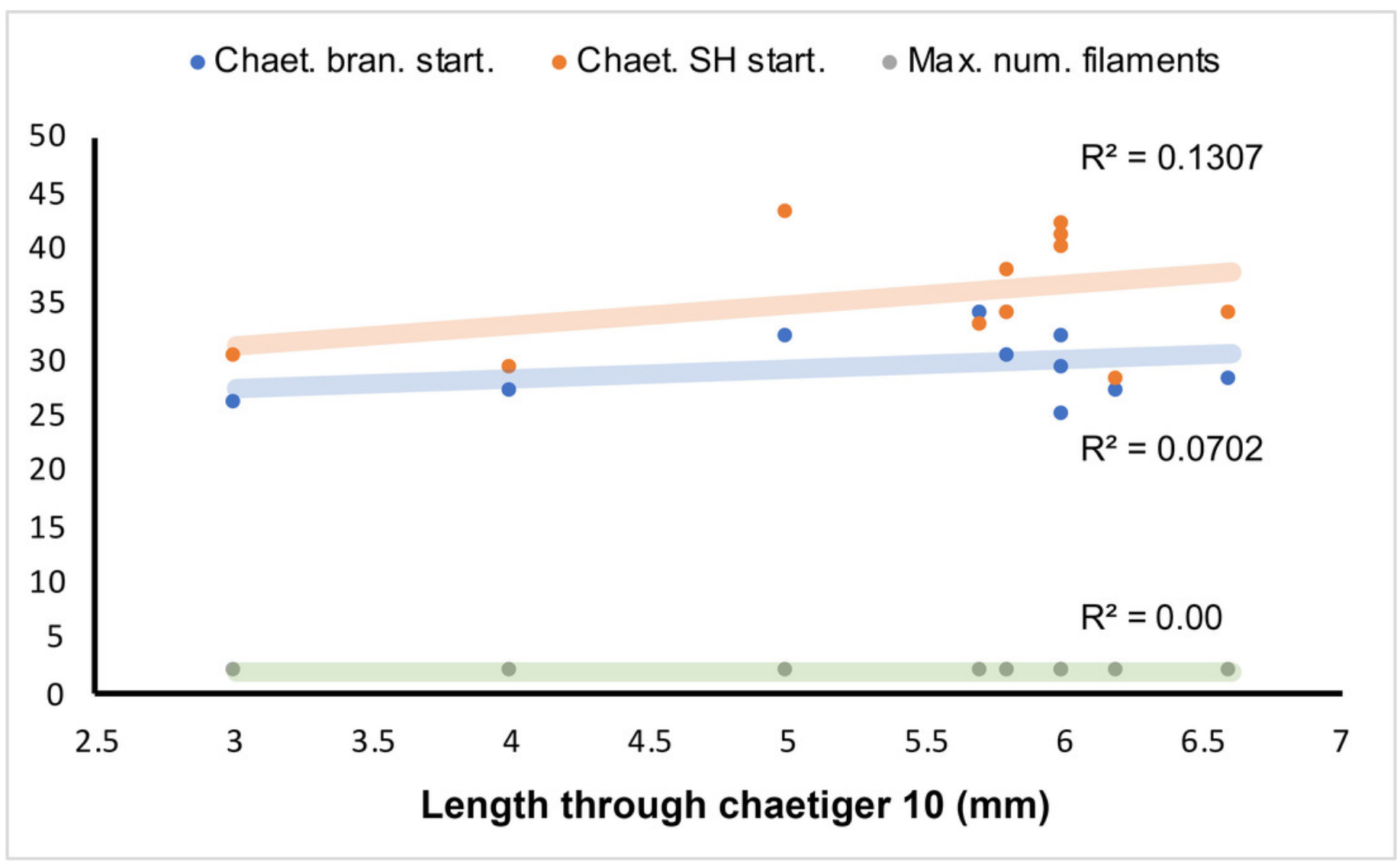




\section{Table 1 (on next page)}

COI sequences of Marphysa taxa used in the phylogenetic analysis

COI sequences of Marphysa taxa used in the phylogenetic analysis, with GenBank accession numbers, museum voucher numbers, type locality of species, location of specimens from which sequences were obtained and references to the respective studies. 
1 Table 1. COI sequences of Marphysa taxa used in the phylogenetic analysis, with GenBank 2 accession numbers, museum voucher numbers, type locality of species, location of specimens from 3 which sequences were obtained and references to the respective studies.

4

\begin{tabular}{|c|c|c|c|c|}
\hline Species & $\begin{array}{c}\text { Genbank accession } \\
\text { number }\end{array}$ & $\begin{array}{l}\text { Type locality } \\
\text { (TL) }\end{array}$ & $\begin{array}{l}\text { Collection } \\
\text { locality }\end{array}$ & Reference \\
\hline $\begin{array}{c}\text { Marphysa } \\
\text { haemasoma }\end{array}$ & MN067877 & $\begin{array}{l}\text { Cape of Good } \\
\text { Hope, South } \\
\text { Africa }\end{array}$ & $\begin{array}{l}\text { Kommetjie, } \\
\text { South Africa }\end{array}$ & $\begin{array}{l}\text { Simon et al. } \\
\text { unpublished } \\
\text { data. }\end{array}$ \\
\hline $\begin{array}{c}\text { Marphysa } \\
\text { sherlockae } \mathrm{n} . \text { sp. }\end{array}$ & $\begin{array}{l}\text { MT840349-- } \\
\text { MT840351 }\end{array}$ & $\begin{array}{l}\text { Durban, South } \\
\text { Africa }\end{array}$ & $\begin{array}{l}\text { Strand, South } \\
\text { Africa }\end{array}$ & This study \\
\hline $\begin{array}{c}\text { Marphysa } \\
\text { aegypti }\end{array}$ & $\begin{array}{c}\text { MF196971, } \\
\text { MF196969, } \\
\text { MF196970, MF196968 }\end{array}$ & $\begin{array}{l}\text { Suez Canal, } \\
\text { Egypt }\end{array}$ & $\begin{array}{c}\text { Suez Canal, } \\
\text { Egypt }\end{array}$ & $\begin{array}{l}\text { Elgetany et al. } \\
2018\end{array}$ \\
\hline $\begin{array}{c}\text { Marphysa } \\
\text { chirigota }\end{array}$ & $\begin{array}{l}\text { MN816441, } \\
\text { MN816442, } \\
\text { MN8164433 }\end{array}$ & $\begin{array}{c}\text { Cádiz Bay, SW } \\
\text { Iberian } \\
\text { Península }\end{array}$ & $\begin{array}{l}\text { Cádiz Bay, } \\
\text { SW Iberian } \\
\text { Península }\end{array}$ & $\begin{array}{l}\text { Martin et al. } \\
\quad 2020\end{array}$ \\
\hline $\begin{array}{c}\text { Marphysa } \\
\text { bifurcata }\end{array}$ & KX172177, KX172178 & $\begin{array}{l}\text { Sheltered North } \\
\text { Reef at Poin } \\
\text { Peron, Western } \\
\text { Australia }\end{array}$ & Australia & $\begin{array}{l}\text { Zanol et al. } \\
2016\end{array}$ \\
\hline $\begin{array}{c}\text { Marphysa } \\
\text { brevitentaculata }\end{array}$ & GQ497548 & $\begin{array}{l}\text { Scarborough, } \\
\text { Tobago, } \\
\text { Trinidad and } \\
\text { Tobago }\end{array}$ & Mexico & $\begin{array}{l}\text { Zanol et al. } \\
2010\end{array}$ \\
\hline $\begin{array}{l}\text { Marphysa } \\
\text { californica }\end{array}$ & GQ497552 & $\begin{array}{l}\text { San Diego } \\
\text { County, } \\
\text { California }\end{array}$ & California & $\begin{array}{l}\text { Zanol et al. } \\
2010\end{array}$ \\
\hline $\begin{array}{c}\text { Marphysa } \\
\text { corallina }\end{array}$ & $\begin{array}{c}\text { KT823271, KT823300, } \\
\text { KT823306, KT823343, } \\
\text { KT823371, KT823389, } \\
\text { KT823410 }\end{array}$ & Hawaii & $\begin{array}{c}\text { Multiple } \\
\text { localities in } \\
\text { KwaZulu- } \\
\text { Natal and } \\
\text { Eastern Cape, } \\
\text { South Africa }\end{array}$ & $\begin{array}{l}\text { Kara et al. } \\
\text { unpublished }\end{array}$ \\
\hline $\begin{array}{l}\text { Marphysa } \\
\text { fauchaldi }\end{array}$ & KX172165 & $\begin{array}{l}\text { off Elizabeth } \\
\text { River, Darwin } \\
\text { region, Australia }\end{array}$ & Australia & $\begin{array}{l}\text { Zanol et al. } \\
2016\end{array}$ \\
\hline Marphysa & MN816444, & Cádiz Bay, SW & Cádiz Bay, & Martin et al. \\
\hline
\end{tabular}




\begin{tabular}{|c|c|c|c|c|}
\hline Species & $\begin{array}{c}\text { Genbank accession } \\
\text { number }\end{array}$ & $\begin{array}{l}\text { Type locality } \\
\text { (TL) }\end{array}$ & $\begin{array}{l}\text { Collection } \\
\text { locality }\end{array}$ & Reference \\
\hline gaditana & $\begin{array}{c}\text { KR916870, } \\
\text { AY040708, } \\
\text { KR916871, } \\
\text { KR916872, KR91687, } \\
\text { KP254503, KP254537, } \\
\text { KP254643, KP254743, } \\
\text { KP254802 }\end{array}$ & $\begin{array}{l}\text { Iberian } \\
\text { Península }\end{array}$ & $\begin{array}{l}\text { SW Iberian } \\
\text { Península } \\
\text { Portugal, } \\
\text { France, } \\
\text { Virginia } \\
\text { (USA) }\end{array}$ & $\begin{array}{l}\text { 2020, Lobo et } \\
\text { al. } 2016, \\
\text { Siddal et al. } \\
\text { 2001, Leray et } \\
\text { al. } 2015\end{array}$ \\
\hline $\begin{array}{c}\text { Marphysa } \\
\text { honkongensa }\end{array}$ & MH598526 & $\begin{array}{l}\text { Tolo Harbour, } \\
\text { Hong Kong }\end{array}$ & China & $\begin{array}{l}\text { Wang et al. } \\
2018\end{array}$ \\
\hline $\begin{array}{l}\text { Marphysa } \\
\text { iloiloensis }\end{array}$ & $\begin{array}{l}\text { MN133418, } \\
\text { MN106279, } \\
\text { MN106280, } \\
\text { MN106281 }\end{array}$ & $\begin{array}{l}\text { Tigbauan, Iloilo } \\
\text { Province }\end{array}$ & Philippines & $\begin{array}{c}\text { Glasby et al. } \\
2019\end{array}$ \\
\hline & $\begin{array}{l}\text { KX172141, } \\
\text { KX172142, } \\
\text { KX172143, } \\
\text { KX172144, } \\
\text { KX172145, } \\
\text { KX172146, } \\
\text { KX172147, } \\
\text { KX172148, } \\
\text { KX172149, } \\
\text { KX172150, }\end{array}$ & $\begin{array}{c}\text { Stingray Bay, } \\
\text { New South } \\
\text { Wales }\end{array}$ & & \\
\hline $\begin{array}{c}\text { Marphysa } \\
\text { kristiani }\end{array}$ & $\begin{array}{c}\text { KX172151, } \\
\text { KX172155, } \\
\text { KX172152, } \\
\text { KX172153, } \\
\text { KX172154, } \\
\text { KX172156, } \\
\text { KX172157, } \\
\text { KX172158, } \\
\text { KX172159, } \\
\text { KX172160, } \\
\text { KX172161, } \\
\text { KX172162, KX172163 }\end{array}$ & & Australia & $\begin{array}{l}\text { Zanol et al. } \\
2016\end{array}$ \\
\hline $\begin{array}{l}\text { Marphysa } \\
\text { mossambica }\end{array}$ & JX559751, KX172164 & Mossambique & $\begin{array}{l}\text { Philippines, } \\
\text { Australia }\end{array}$ & $\begin{array}{c}\text { Zanol et al. } \\
\text { 2010, Zanol et } \\
\text { al. } 2016\end{array}$ \\
\hline Marphysa & KX172166, & & Australia & Zanol et al. \\
\hline
\end{tabular}




\begin{tabular}{|c|c|c|c|c|}
\hline Species & $\begin{array}{c}\text { Genbank accession } \\
\text { number }\end{array}$ & $\begin{array}{l}\text { Type locality } \\
\text { (TL) }\end{array}$ & $\begin{array}{l}\text { Collection } \\
\text { locality }\end{array}$ & Reference \\
\hline mullawa & $\begin{array}{c}\text { KX172167, } \\
\text { KX172168, } \\
\text { KX172169, } \\
\text { KX172170, } \\
\text { KX172171, } \\
\text { KX172172, } \\
\text { KX172173, } \\
\text { KX172174, } \\
\text { KX172175, KX172176 }\end{array}$ & $\begin{array}{l}\text { Moreton Bay, } \\
\text { Fisherman's } \\
\text { Island, } \\
\text { Queensland }\end{array}$ & & 2016 \\
\hline $\begin{array}{c}\text { Marphysa } \\
\text { pseudosessiloa }\end{array}$ & KY605405, KY605406 & $\begin{array}{c}\text { Careel Bay, } \\
\text { New South } \\
\text { Gales }\end{array}$ & Australia & $\begin{array}{c}\text { Zanol et al. } \\
2017\end{array}$ \\
\hline Marphysa regalis & GQ497562 & Bermuda & Brazil & $\begin{array}{c}\text { Zanol et al. } \\
2016\end{array}$ \\
\hline Marphysa victori & $\begin{array}{l}\text { MG384996, } \\
\text { MG384999, } \\
\text { MG384997, } \\
\text { MG384998 }\end{array}$ & Arcachon Bay & France & $\begin{array}{l}\text { Lavesque et } \\
\text { al. } 2017\end{array}$ \\
\hline Marphysa viridis & GQ497553 & $\begin{array}{l}\text { Boca Grande } \\
\text { Key, Florida }\end{array}$ & Brazil & $\begin{array}{l}\text { Zanol et al. } \\
2010\end{array}$ \\
\hline $\begin{array}{l}\text { Marphysa } \\
\text { sanguinea }\end{array}$ & $\begin{array}{l}\text { GQ497547, } \\
\text { MK541904, } \\
\text { MK950851, } \\
\text { MK950852, } \\
\text { MK950853, } \\
\text { MK967470, } \\
\text { MN106282, } \\
\text { MN106283, } \\
\text { MN106284 }\end{array}$ & $\begin{array}{l}\text { Polperro, } \\
\text { Cornwall }\end{array}$ & $\begin{array}{c}\text { Cornwall } \\
\text { (UK), France }\end{array}$ & $\begin{array}{l}\text { Zanol et al. } \\
2010, \\
\text { Lavesque et } \\
\text { al. } 2019 \text {, } \\
\text { Glasby et al. } \\
2019\end{array}$ \\
\hline $\begin{array}{l}\text { Marphysa } \\
\text { tripectinata }\end{array}$ & $\begin{array}{l}\text { MN106271, } \\
\text { MN10622, } \\
\text { MN1062723, } \\
\text { MN106274, } \\
\text { MN106275, } \\
\text { MN106276, } \\
\text { MN106277, } \\
\text { MN106278 }\end{array}$ & Beihai, China & China & Liu et al. 2017 \\
\hline
\end{tabular}

Marphysa sp. KP255196, KP254890, - $\quad$ K $\quad$ Florida (USA), Leray et al. 


\begin{tabular}{|c|c|c|c|c|}
\hline Species & $\begin{array}{c}\text { Genbank accession } \\
\text { number }\end{array}$ & $\begin{array}{l}\text { Type locality } \\
\text { (TL) }\end{array}$ & $\begin{array}{l}\text { Collection } \\
\text { locality }\end{array}$ & Reference \\
\hline & $\begin{array}{l}\text { KP254644, KP254223, } \\
\text { NC023124, KF733802 }\end{array}$ & & China & $\begin{array}{c}2015, \mathrm{Li} \text { et al. } \\
2016\end{array}$ \\
\hline $\begin{array}{c}\text { Paucibranchia } \\
\text { bellii }\end{array}$ & KT307661 & $\begin{array}{c}\text { Chausey } \\
\text { Island, France }\end{array}$ & Spain & $\begin{array}{c}\text { Aylagas et al. } \\
2016\end{array}$ \\
\hline $\begin{array}{c}\text { Paucibranchia } \\
\text { disjuncta }\end{array}$ & GQ497549 & $\begin{array}{c}\text { Los Angeles } \\
\text { County, } \\
\text { California }\end{array}$ & $\begin{array}{l}\text { California, } \\
\text { USA }\end{array}$ & $\begin{array}{l}\text { Zanol et al. } \\
2010\end{array}$ \\
\hline $\begin{array}{c}\text { Paucibranchia } \\
\text { sp. }\end{array}$ & JX559753 & & Phillipines & $\begin{array}{l}\text { Zanol et al. } \\
2014\end{array}$ \\
\hline Palola viridis & GQ497556 & Samoa & Micronesia & $\begin{array}{l}\text { Zanol et al. } \\
2010\end{array}$ \\
\hline $\begin{array}{c}\text { Eunice cf. } \\
\text { violaceomaculata }\end{array}$ & GQ497542 & - & Belize & $\begin{array}{l}\text { Zanol et al. } \\
2010\end{array}$ \\
\hline Leodice rubra & GQ497528 & - & Brazil & $\begin{array}{l}\text { Zanol et al. } \\
2010\end{array}$ \\
\hline Hyalinoecia sp. & GQ497524 & - & $\begin{array}{l}\text { Massachusetts, } \\
\text { USA }\end{array}$ & $\begin{array}{l}\text { Zanol et al. } \\
2010\end{array}$ \\
\hline
\end{tabular}


